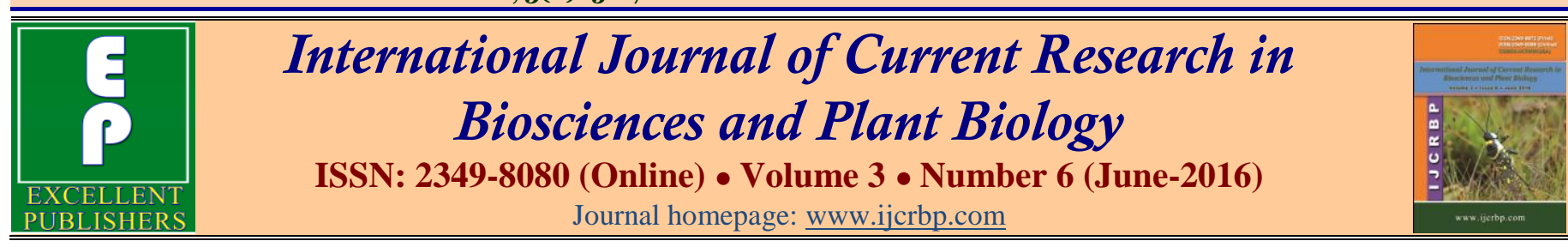

\title{
Ethnobotanical Survey of Fodder/Forage Plant Species in Range and Farming Systems in the Savannahs of Ngoketunjia, North Western Cameroon
}

\author{
Celestine Fonyikeh-Bomboh Lucha ${ }^{1,2 *}$ and George Bindeh Chuyong ${ }^{2}$ \\ ${ }^{1}$ Department of Plant Biology, Faculty of Science, P.O Box 67, University of Dschang, Cameroon \\ ${ }^{2}$ Department of Botany and Plant Physiology, Faculty of Science, P.O Box 63, University of Buea, Cameroon \\ *Corresponding author.
}

\begin{tabular}{|c|c|}
\hline Abstract & Article Info \\
\hline \multirow{3}{*}{$\begin{array}{l}\text { The world is changing. Desertification, climate change, non-sustainable agricultural and } \\
\text { environmental practices like bush fires are leading to decrease in biological diversity } \\
\text { and the appearance of invasive species. Ethnobotanical surveys were carried out in the } \\
13 \text { villages of Ndop, Ngoketunjia Division, Cameroon, to explore the ethnobotanical } \\
\text { knowledge of the local people in Ngoketunjia Division; to raise awareness among the } \\
\text { local community about the protection of native fodder/forage flora; and to propose } \\
\text { guidelines for proper utilization, management and conservation of useful plants and the } \\
\text { landscape, contributing in improving on the livelihood of the rural and urban population. } \\
\text { Regular field trips were made and data were collected using Show and Tell Semi- } \\
\text { structured Interviews employing a checklist of questions, guided field walks, } \\
\text { discussions and direct field observations. The plant inventory of } 151 \text { species belonging } \\
\text { to } 105 \text { genera and } 44 \text { families was constructed, including their common/vernacular } \\
\text { name, life form, part used, animal, threats and availability of these plants. The leaves of } \\
\text { these species were the most commonly used plant parts. Plants were collected, } \\
\text { identified, preserved, mounted and voucher specimens were deposited at the National } \\
\text { Herbarium and the University of Dschang Herbaria for future references. }\end{array}$} & $\begin{array}{l}\text { Accepted: } 23 \text { May } 2016 \\
\text { Available Online: 06 June } 2016\end{array}$ \\
\hline & Keywords \\
\hline & $\begin{array}{l}\text { Ethnobotany } \\
\text { Fodder/Forage plants } \\
\text { Ngoketunjia } \\
\text { North-western Cameroon } \\
\text { Savannahs }\end{array}$ \\
\hline
\end{tabular}

\section{Introduction}

Savannahs are tropical and sub-tropical grasslands with scattered trees and they occupy about $20 \%$ of the land surface of the Earth and $40 \%$ of Africa (van Wilgen et al., 2000). Desertification, climate change, nonsustainable agricultural and environmental practices like bush fires are leading to decrease in biological diversity and the appearance of invasive species in the savannahs of north western Cameroon, as they are elsewhere in Africa. Measures to improve ecosystem health and maintain species diversity can't be effectively maintained without knowledge of species present. Of all savannah species, those used as pasture are a critical component in livestock agriculture and hence human welfare.

Livestock rearing is an occupation and source of income for the majority of resource-poor farmers in the area. Ruminant livestock play a very important role in Cameroon agriculture, contributing about $9 \%$ of the total agricultural output or about $2.1 \%$ of the gross domestic product (MINEPIA, 2002). This subsector is a source of revenue to more than $30 \%$ of the rural population. North West Region is one of the major cattle production regions in Cameroon, with Ngoketunjia division being the major transhumance zone (seasonal displacement of flocks from one area to another, by herders in search of pasture and water). Pastures are the main land-use 
system in the Ngoketunjia of Cameroon. Livestock find their fodder in the natural savannahs. The available grazing is degrading and not sufficient to meet the maintenance requirements of animals. In the savannahs of north western Cameroon, they practice extensive animal production that results in soil fertility decline, poor crop-tree-livestock integration, and increased encroachment on fragile areas (The World Bank, 2012). With the current increase in crop area, coupled with population growth, less land is available for grazing. Forage forms the main and cheapest feed for ruminants (Pamo et al., 2006a and 2006b) and pressure on forage resources is increasing.

Current knowledge about the plant species used as fodder/forage is poor. However, there is a fund of potentially useful knowledge in the folk traditions of local farmers. Ethnobotany is an integral part of indigenous/local knowledge of a particular society (Osawaru and Danin-Ogbe, 2010). However, some of the knowledge is liable to be distorted or lost completely if transfer is not done continuously.

This research was therefore an effort to document and to preserve this folk asset of indigenous knowledge on plants to make it available to present and future generations. More comprehensive identification of forage species, and preliminary assessment of their abundance, would also contribute to some of the Millennium Development Goals (MDGs) of poverty eradication and environmental sustainability, while assisting Cameroon to meet obligations under the Convention on Biological Diversity (CBD, 2014).

Specific objectives of the present research work were (1) to explore the ethnobotanical knowledge of the local people in Ngoketunjia Division; (2) to raise awareness among the local community about the protection of native fodder/forage flora; and (3) to propose guidelines for proper utilization, management and conservation of useful plants and the landscape.

\section{Materials and methods}

\section{The study area: Location}

The study was carried out in Ngoketunjia Division of the North West Region of Cameroon (Fig. 1). Ngoketunjia Division is bordered by Bui Division to the north, Mezam Division to the west, Bamboutos and Noun Divisions to the south and east respectively. It lies between latitudes $5^{\circ} 15^{\prime}$ and $6^{\circ} 10^{\prime} \mathrm{N}$ and $10^{\circ} 15^{\prime}$ and $10^{\circ} 40^{\prime} \mathrm{E}$ (Wirsiy, 2011). The division covers a surface area of $1.152 \mathrm{~km}^{2}$ with a population of about 230,501 inhabitants [projection from the 2005 population census (considering the national annual population growth rate of $2.5 \%$ )] giving a population density of 200 inhabitants per $\mathrm{km}^{2}$ (Mbarga, 2010). It has an active farming population of about 184,401 persons (80\% of 230,501) with 30,734 farm families (Wirsiy, 2013). The population is high and increasing, naturally, and through immigration, and people are poor.The main ethnic group is the Tikari tribe (Nkouandou, 2005).

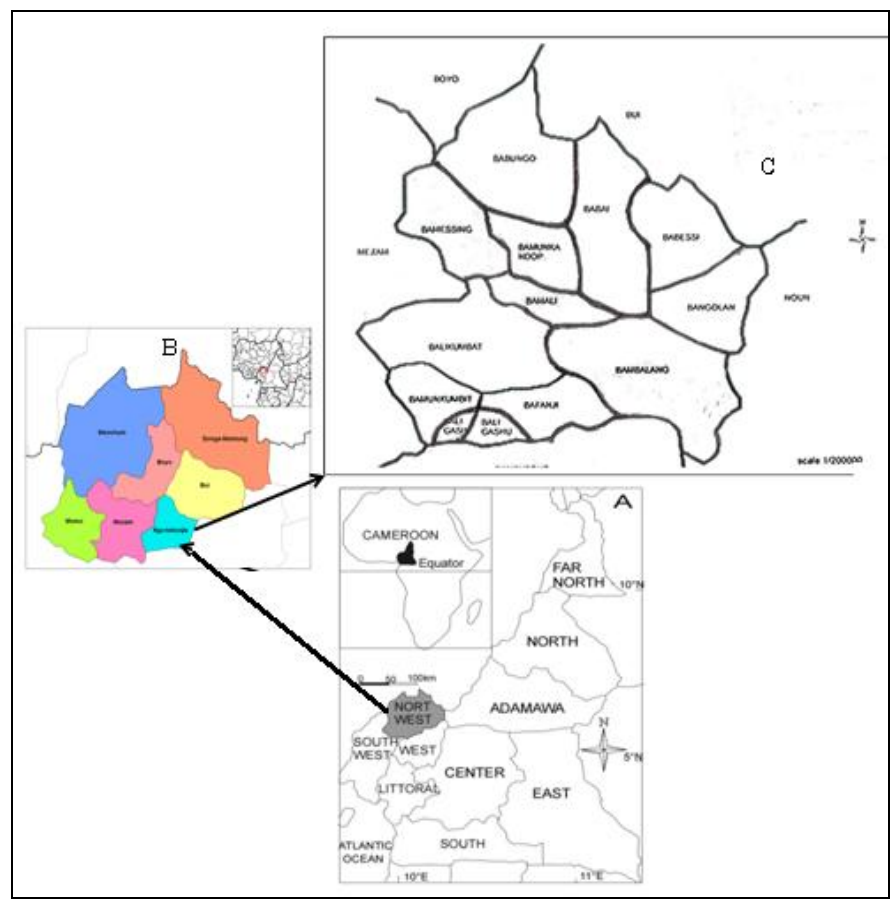

Fig. 1: Geographical location of study area. A: North West Region of Cameroon, B: Ngoketunjia Division in the North West Region, C: Ngoketunjia Division. Source: Adapted from the map of the North West Region.

\section{Nature of the survey location}

The relief is characterized by the Ndop Plain surrounded by numerous hills which are catchments for several rivers. Ndop plain is an intermontane basin in the Bamenda Highlands (Neba, 2009). It ranges from 300 to $2000 \mathrm{~m}$ in altitude (Nkouandou, 2005) and the average altitude is $1200 \mathrm{~m}$ (MINEF, 1999). The climate is subtropical with low temperatures and two distinct seasons; a dry season from mid-November to mid-March and a rainy season which extends from mid-March to midNovember. Annual rainfall is estimated at $1600 \mathrm{~mm}$ (Nkouandou, 2005) and the mean annual temperature is approximately $30^{\circ} \mathrm{C}$ (MINEF, 1999). The vegetation is principally savannah with stunted trees and a few tree 
plantations (Fig. 2). The soil type is sandy loam, clay and alluvial deposits (Wirsiy, 2011). Consequently, the human pressure on the resources of the area is extremely high and the overall biodiversity and a number of key species are under threat. The main activity of the people is agriculture and fishing, with grazing, bushfires, overharvesting of firewood and medicinal plants predominant. Maize is the main subsistence food crop and the main cash crop is rice which is cultivated on an industrial scale by the Upper Nun Valley Development Authority (UNVDA).

\section{Ethnobotanical surveys}

Ethnobotanical surveys were carried out in the 13 villages of Ngoketunjia Division in July 2011 - July 2013, to investigate, create awareness, collect, identify, document the indigenous knowledge of local people about the plants used as fodder/forage and the threats to their survival, to guide proper utilization, management, conservation of useful plants and the landscape and to contribute in improving on the livelihood of the rural and urban population.

Regular field trips were made and data were collected using Show and Tell Semi-structured Interviews (Fig. 3
A, B) employing a checklist of questions, guided field walks, discussions and direct field observations (Bahru et al., 2014, Zereen and Khan, 2012, Bele et al., 2011).

\section{Collection and preservation of plants}

Frequent field trips were carried out to collect the live specimens of the plants used as fodder/forage (Fig. $3 \mathrm{C}$, $\mathrm{D}$ and $\mathrm{E})$. The data taken in the field was transferred to the slip pasted on the herbarium sheets. The samples were dried. The samples were identified with the help of available taxonomic literature, manuals and floras and comparing with the already identified plant specimens of the herbarium. Identification was then confirmed by senior botanists at the National Herbarium (Fig. $3 \mathrm{~F}$ and $\mathrm{G})$. The dried specimens were then mounted on herbarium sheets, voucher specimens were deposited in the National Herbarium (HNC), and the University of Dschang herbaria for future references.

\section{Check list and ethnobotanical inventory}

Ethnobotanical inventory was developed consisting of Plant families, scientific names, Common and vernacular names, part used, animals, the threats and availability of the plants.
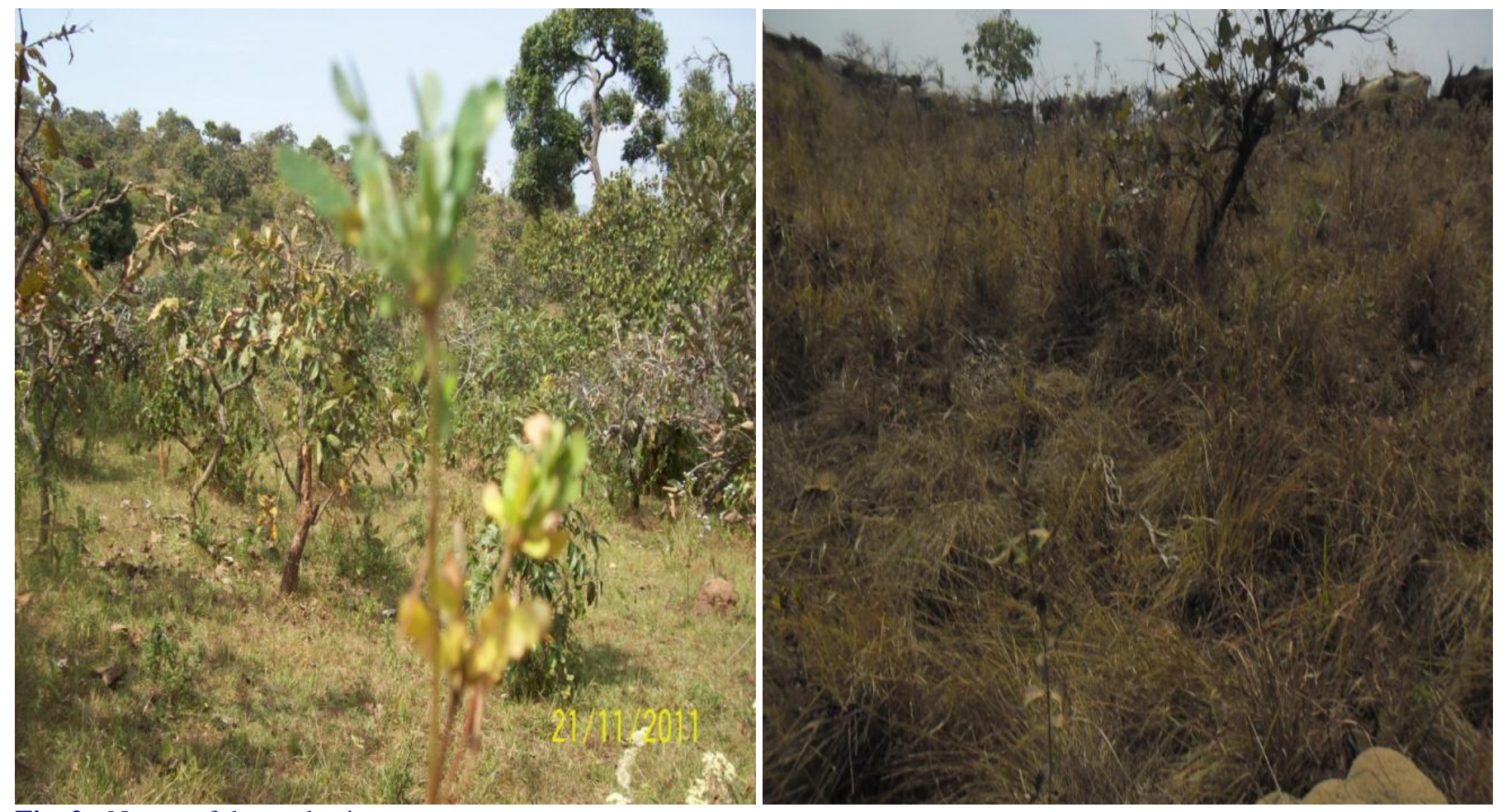

Fig. 2: Nature of the study sites. 


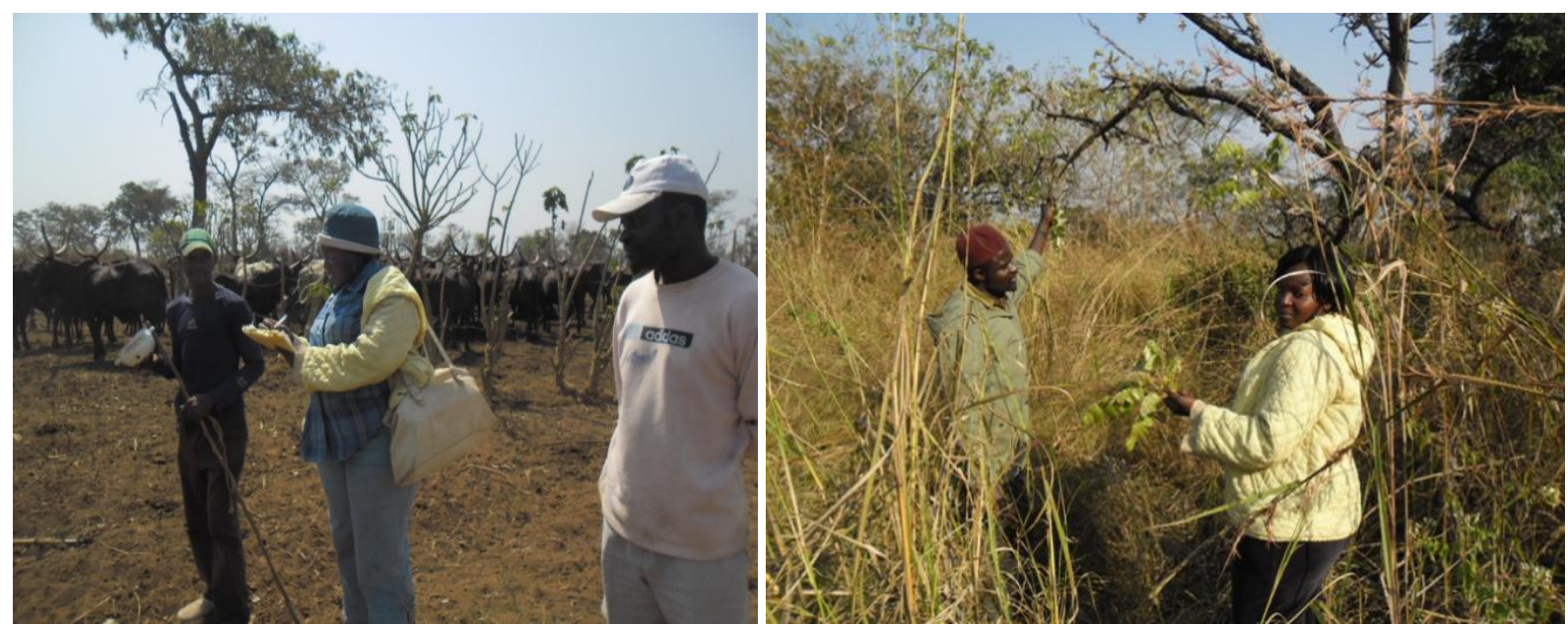

Fig. 3A and B: Sampling interview and guided Field walk in Ngoketunjia, Cameroon.
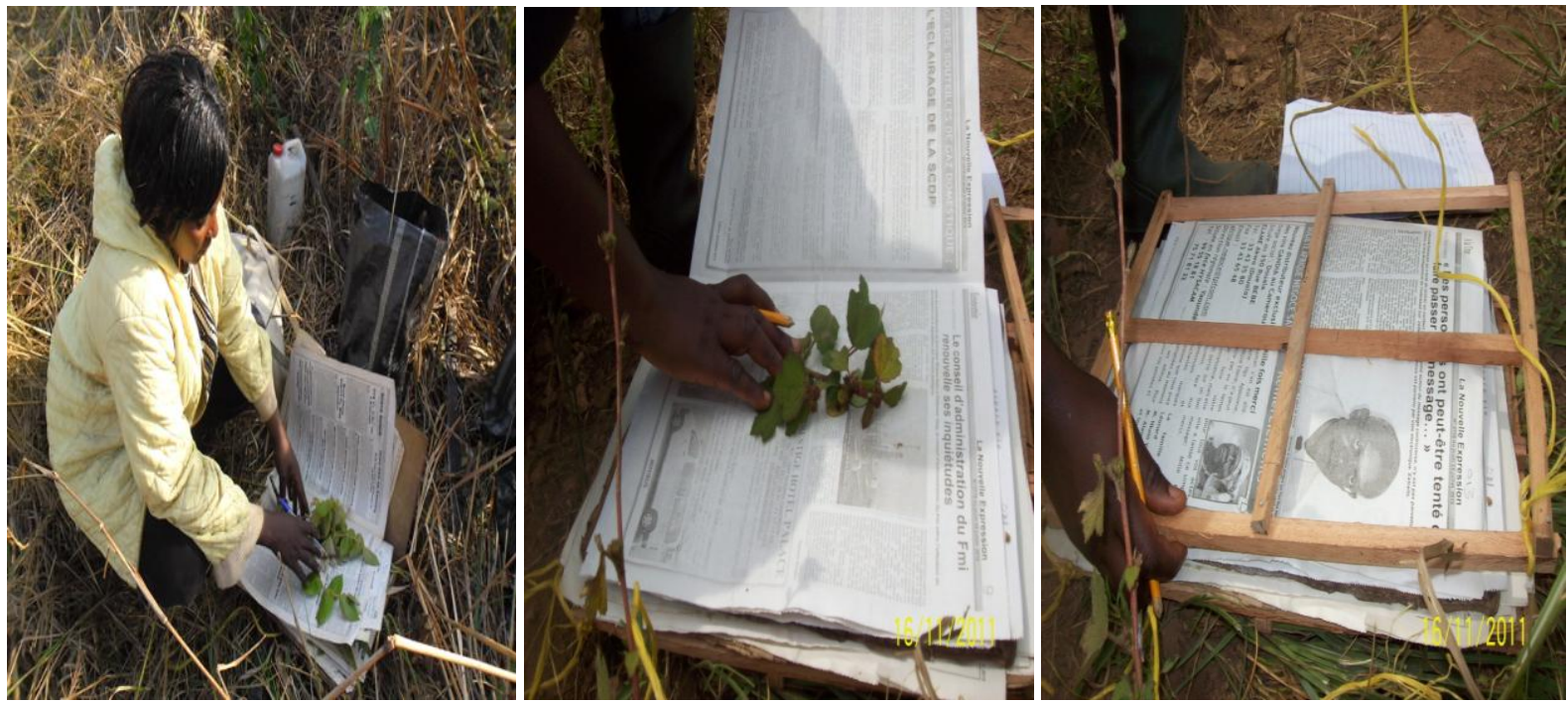

Fig. 3: C, D and E: Collection and pressing of fodder plant samples in Ndop, Cameroon.
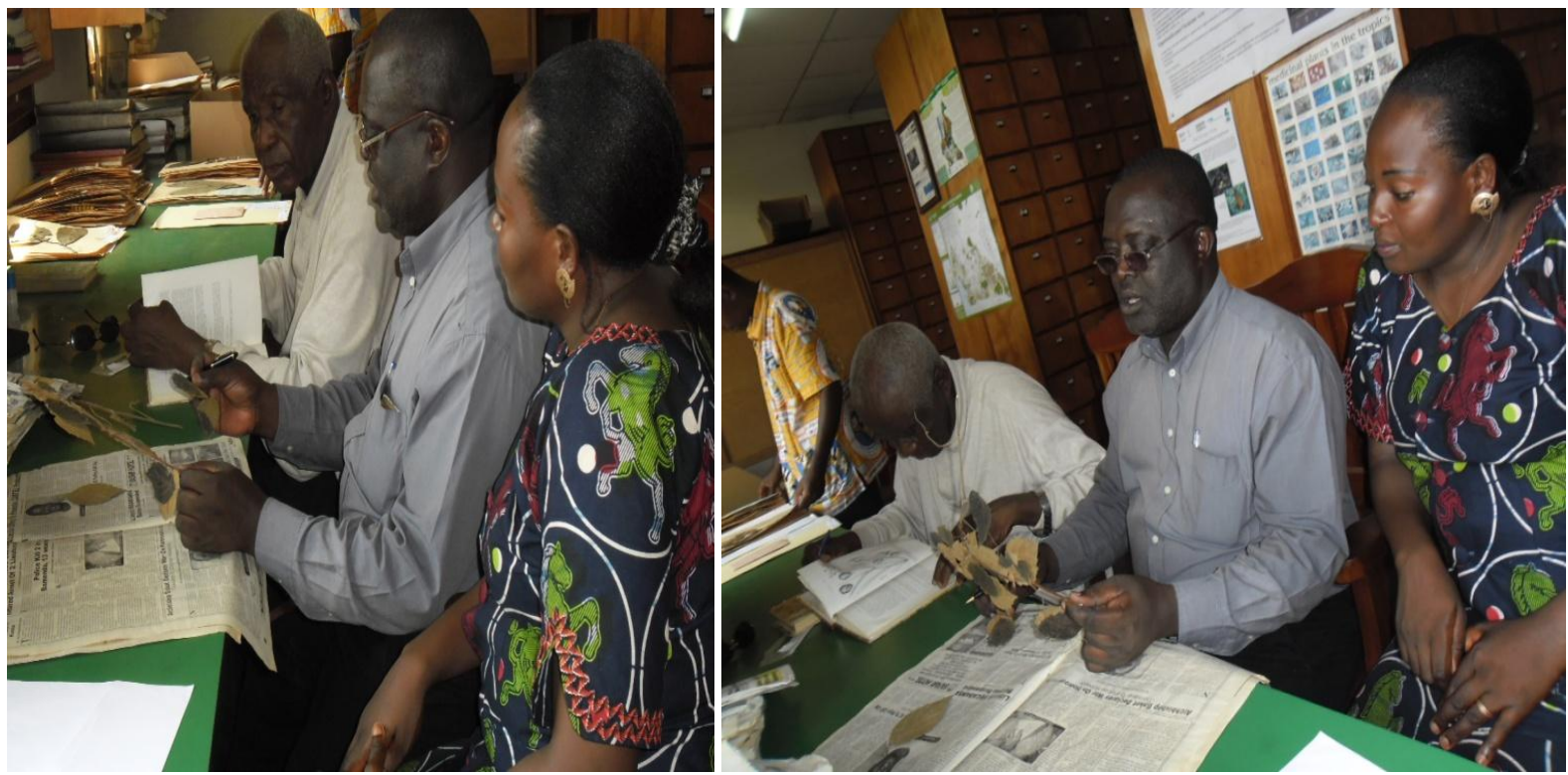

Fig. 3: F and G: Identification and confirmation of fodder plants at the National Herbarium of Cameroon.

C. F. Lucha and G. B. Chuyong (2016) / Ethnobotanical Survey of Fodder/Forage Plant Species in Range and Farming Systems in the Savannahs of Ngoketunjia, North Western Cameroon 


\section{Statistical analysis}

The data analysis was performed using Microsoft Office Excel 2007, and descriptive statistics (frequencies and percentages were presented).

\section{Results}

\section{Distribution of people interviewed}

Eight hundred and three people were interviewed amongst which 484 were from Ndop Central sub-division, 203 from Babessi sub-division and 116 from Balikumbat subdivision. With respect to cultural groups, the Tikari (55\%) had the highest number of people who participated during the inquiry, followed by the Mbororo (40\%) then the Hausa $(5 \%)$. The farmers $(60 \%)$ were the majority of people interviewed followed by the herders (23\%) (Fig. 4).

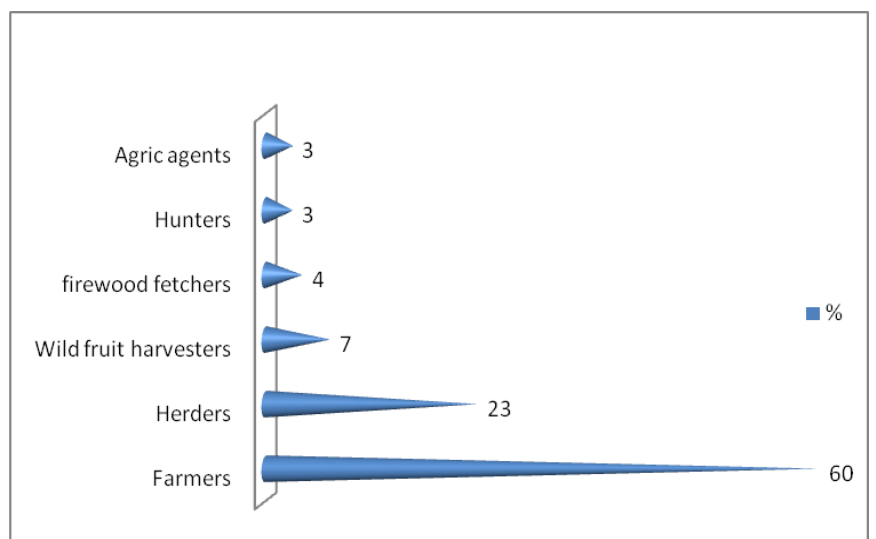

Fig. 4: Distribution of people interviewed in terms of occupation in Ngoketunjia, Cameroon

The informants were interviewed following different age groups and sexes. Those ages between 12 and 21 were considered to be youths, and between 21 and 50 were considered to be adults, and those $>50$ years were considered to be the old. In terms of gender, the sample was fairly balanced, as there were females $(55.6 \%)$ and males $(44.4 \%)$. The distribution of people interviewed in terms of age groups shows that the adults $(50.07 \%)$ had the highest number of informants, followed by the old $(30.09 \%)$ and lastly the youths (19.84\%).

\section{Plants sampled}

The plant inventory of 151 species belonging to 105 genera and 44 families was constructed, including their common/vernacular name (Appendix 1), life form, part used, animal (Appendix 2), threats and availability of these plants. The plant families with more species were
Poaceae (31 species), Fabaceae (22 species) and Asteraceae (14 species) (Fig. 5; Table 1).

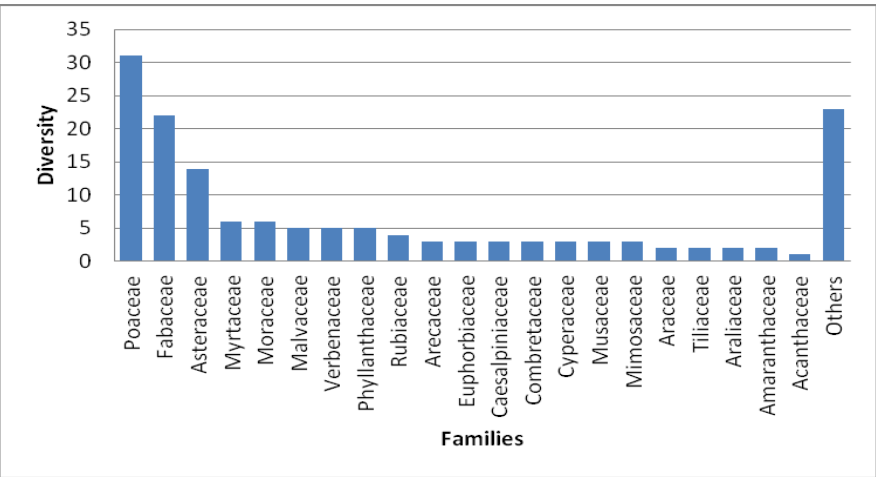

Fig. 5: Specific diversity of the fodder/forage plant families. The numbers of recorded species are indicated for every family.

The fodder/forage plant species have different life forms and parts used and different animals feed on them (Appendix 2).

\section{The frequency of fodder plants in Ndop}

Pennisetum purpureum, Brachiaria spp., Oryza sativa and Zea mays had the highest frequencies (Fig. 6). The plant species are arranged in decreasing order of frequency (Appendix 3).

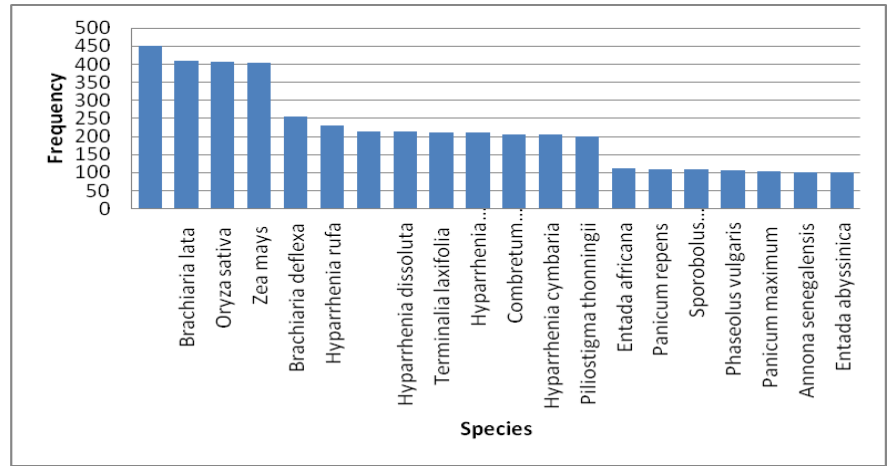

Fig. 6: Species with the highest values of frequency.

Distribution of plants with respect to their morphology

The majority of plants used as fodder were herbs, followed by shrubs, which is closely followed by trees (Fig.7).

\section{Frequency of plant parts used as fodder}

The leaves were the most utilized plant part (44\%). The least utilized plant part was the root (0.6\%) (Fig. 8). 


\section{The frequency of threats to the fodder plants}

Uncontrolled fire had the highest frequency of threats $(31.2 \%)$, followed by overexploitation $(26.6 \%)$, which is followed by the use of herbicides (16.7\%) (Fig. 9).

\section{The availability of the fodder plants in Ndop}

The majority of the plants are getting rare $(56 \%), 25 \%$ of plants are available and $16 \%$ are rare and very rare plants (Fig.10).

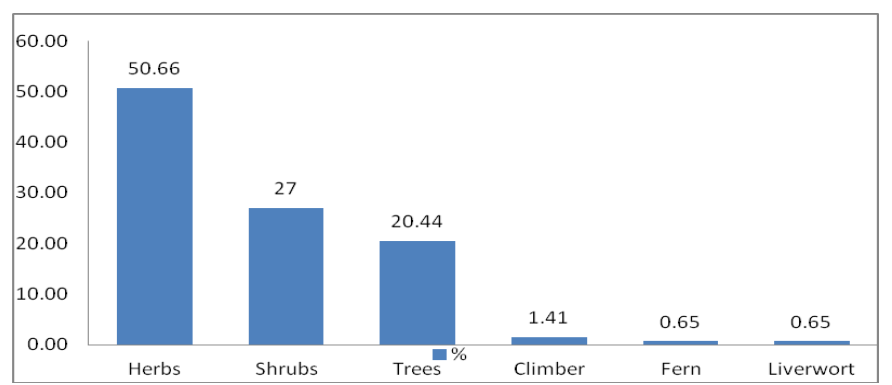

Fig. 7: Life forms of the fodder/forage plants in Ngoketunjia Division, Cameroon.

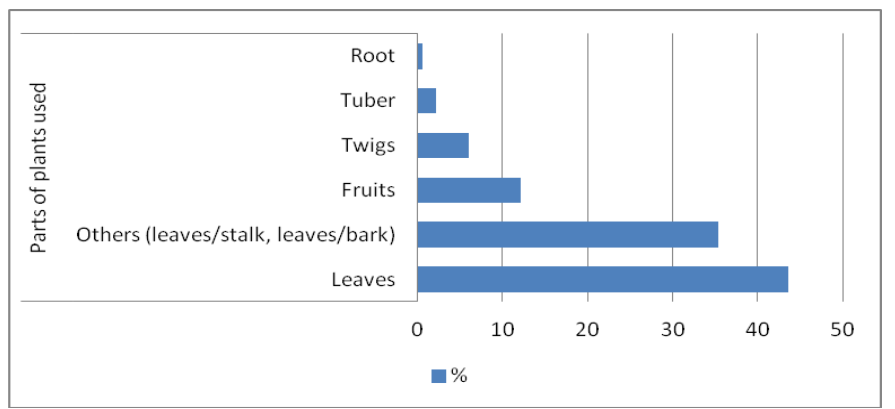

Fig. 8: Distribution of plants according to parts used as fodder in Ngoketunjia Division, North West Region, Cameroon.

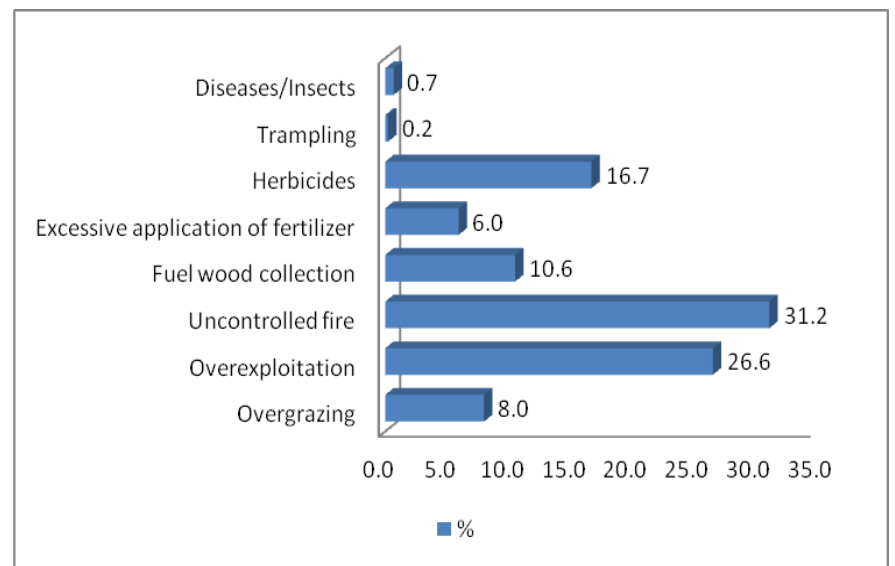

Fig. 9: The threats to the fodder plants in Ngoketunjia Division Cameroon.

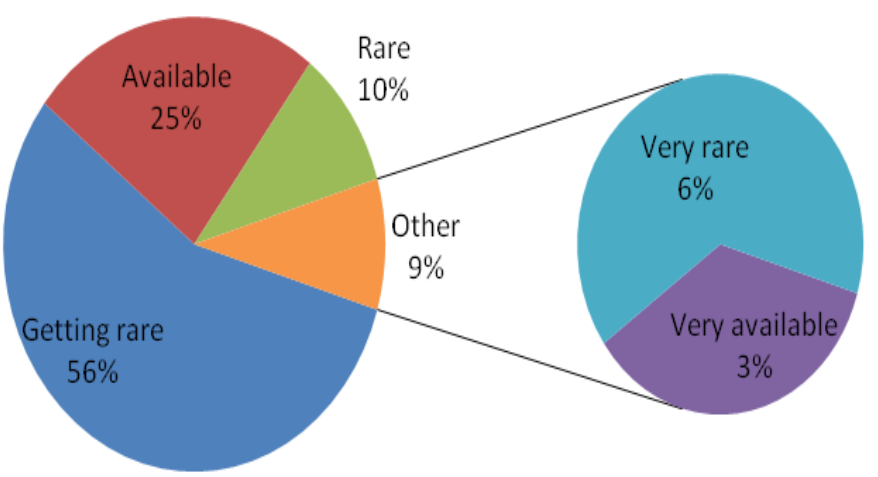

Fig. 10: The availability of the fodder plants in Ngoketunjia Division, Cameroon.

\section{Frequency of animals}

The goats were the highest $(25.42 \%)$, followed by the sheeps $(23.73 \%)$, which is closely followed by the cattle $(23.35 \%)$ (Table 2).

Table 1. Diversity of 44 families in function of species.

\begin{tabular}{lll}
\hline Families & $\mathbf{N}_{\mathbf{G}}$ & $\mathbf{N}_{\mathbf{E}}$ \\
\hline Poaceae & 19 & 31 \\
Fabaceae & 16 & 22 \\
Asteraceae & 9 & 14 \\
Myrtaceae & 3 & 6 \\
Moraceae & 1 & 6 \\
Malvaceae & 4 & 5 \\
Verbenaceae & 3 & 5 \\
Phyllanthaceae & 2 & 5 \\
Rubiaceae & 3 & 4 \\
Arecaceae & 3 & 3 \\
Euphorbiaceae & 3 & 3 \\
Caesalpiniaceae & 2 & 3 \\
Combretaceae & 2 & 3 \\
Cyperaceae & 2 & 3 \\
Musaceae & 2 & 3 \\
Mimosaceae & 1 & 3 \\
\hline
\end{tabular}




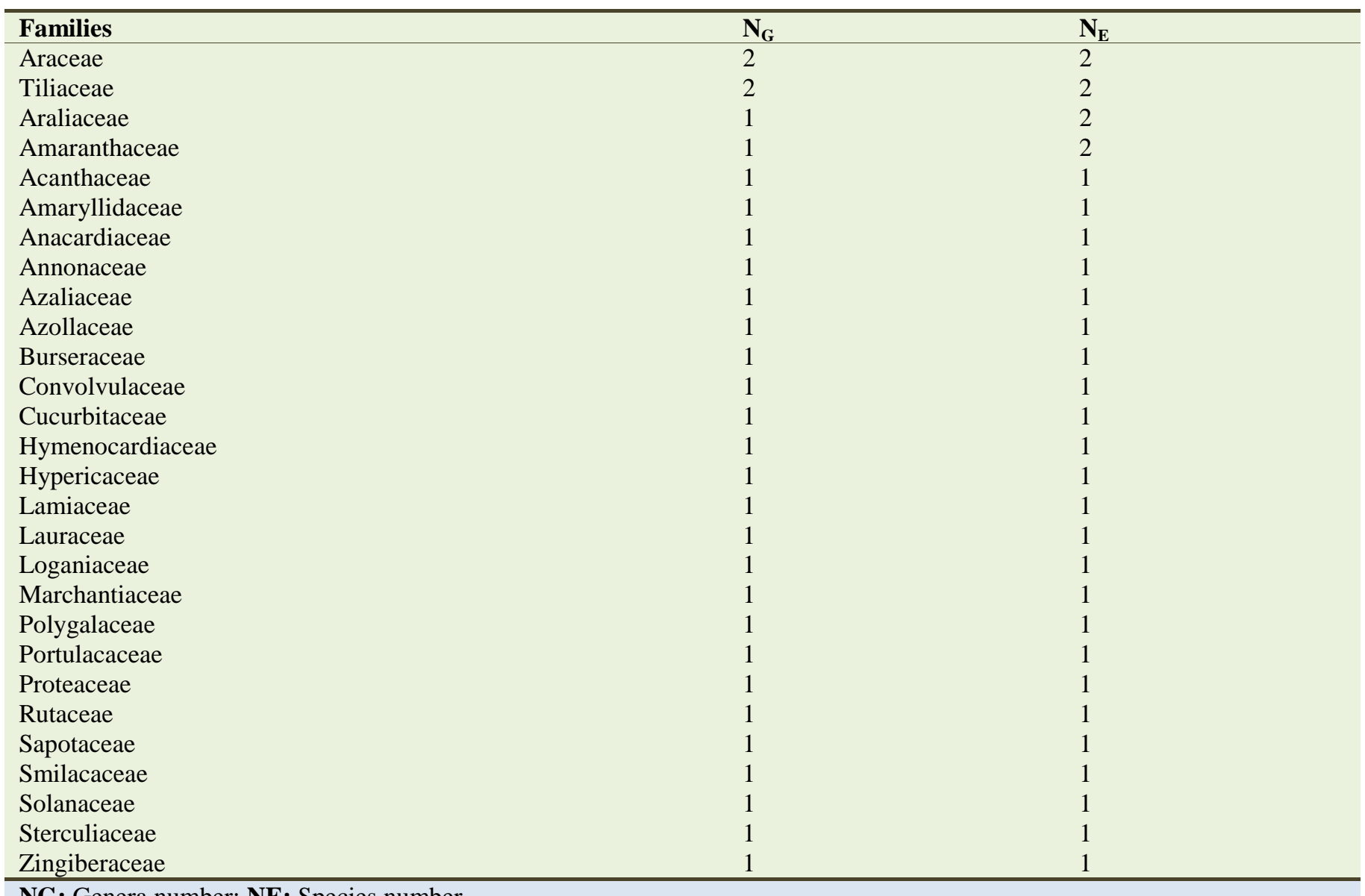

NG: Genera number; NE: Species number.

Table 2. The animals that feed on the fodder/forage plants in Ngoketunjia.

\begin{tabular}{lll}
\hline Animal & Frequency & Percentage (\%) \\
\hline Goats & 135 & 25.42 \\
Sheeps & 126 & 23.73 \\
Cattle & 124 & 23.35 \\
Horses & 56 & 10.55 \\
Rodents & 17 & 3.20 \\
Pigs & 14 & 2.64 \\
Monkeys & 9 & 1.69 \\
Bats & 8 & 1.51 \\
Birds & 8 & 1.51 \\
Grass cutters & 8 & 1.51 \\
Chickens & 5 & 0.94 \\
Squirel & 4 & 0.75 \\
Rabbits & 4 & 0.75 \\
Giant rats & 4 & 0.75 \\
Guinea pigs & 3 & 0.56 \\
Gorilla & 2 & 0.38 \\
Chimpanzees & 1 & 0.19 \\
Donkeys & 1 & 0.19 \\
Antelopes & 1 & 0.19 \\
Rats & 1 & 0.19 \\
\hline Total & $\mathbf{5 3 1}$ & $\mathbf{1 0 0 . 0 0}$ \\
\hline
\end{tabular}

The frequency of animal is the number of time the animal was mentioned. 


\section{Discussion}

Sustainable production of livestock usually involves efficient utilisation of locally available resources. Fodder herbs, trees and shrubs are the diet of these animals and constitute the main source of proteins, minerals and vitamins. Out of the 151 plant species sampled, 131 are not in the list of animal feed resources information system (Only 20 species sampled are in the list of animal feed resource information system- INRA CIRAD AFZ and FAO (Feedipia, 2012-2013). 134 species were not cited in the Cameroon country pasture/forage resource profiles (Only 17 species were reported in the country pasture) (Pamo, 2008).

Only nine of the species were cited by Neba, 2010 as trees and shrubs of the silvopastoral systems of the Bamenda highlands of Cameroon; these are Mangifera indica, Piliostigma thonningii, Vernonia amygdalina, Bridelia micrantha, Albizia gummifera and Albizia zygia. To the best of my knowledge all the plant species sampled are being documented for the first time as fodder/forage plants in Ngoketunjia.

Bidens pilosa, Cajanus cajan, Ficus benghalensis, Oryza sativa and Zea mays are also used as fodder in Nepal (Malla and Chhetri, 2009). Only 14 of the plants sampled were cited by Speedy and Pugliese, 2011 as trees and shrubs of known fodder value in tropical humid Africa. Two of the plants (crop legumes) Arachis hypogea and Vigna unguiculata were reported to have valuable hay sold in Mali (Speedy and Pugliese, 2011). Fodder herbs, shrubs and trees play a significant role both in farming systems (as fallow species) and in livestock production. Jamala et al., 2013 stated that just 4 of the trees and shrubs; Annona senegalensis, Leucaena leucocephala, Gardenia ternifolia and Gliricidia sepium are also used in Nigeria in both farming and livestock production systems. In Rwanda, Calliandra calothysus, Leucaena leucocephala and Pennisetum purpureum are used as fodders to ruminants within agroforestry systems (Holmström, 2013).

Asah 1994 and Zimmermann 1996 cited 12 of the species as Indigenous woody species feasible for integration in crop production systems of Ndop Plain. These are Albizia adianthifolia, Albizia gummifera, Albizia zygia, Bridelia speciosa, Calliandra calothyrsus, Cassia siamea, Entada abyssinica, Erythrina sigmoides, Leucaena leucocephala, Piliostigma thonningii, Polyscia fulva and Sesbania marcrantha. Konsala et al. (2013) cited Piliostigma thonningii, Erythrina Sigmoidea,
Alchornea cordifolia, Bridelia ferruginea and Syzygium guineense var. macrocarpum as woody species used as fodder in Cameroon and Annona senegalensis, Terminalia glaucescens, Vernonia guineense and Piliostigma thonningii as woody species used to treat animal diseases. Pennisetum purpureum, Ipomoea batatas and Sorghum bicolor are also used as forage crops in Western Kenya (Muyekho et al., 2005).

In India 14 of the plants sampled are wild fodder plants which are Mangifera indica, Ficus benghalensis, Portulaca oleracea, Amaranthus spinosus, Lantana camara, Phoenix sylvestris, Eragrostis tenella, Imperata cylindrica and Panicum repens (Ghosh, 2012). In India Rice, maize, sorghum, napier grass (elephant grass) and banana are also used as fodder crops (ILRI, 2010).

Tabuti and Lye, 2009 reported 11 of these plants as fodder plants for cattle in Kaliro district, Uganda. These are Mangifera indica, Bidens pilosa, Vernonia amygdalina, Sesbania sesban, Albizia zygia, Echinochloa pyramidalis, Hyparrhenia rufa, Imperata cylindrica, Panicum maximum, Pennisetum polystachion and Pennisetum purpureum. Some of the plants sampled are used as food and fodder like the maize and rice. Ipomoea batatas is used as food, fodder and fuel (Jata et al., 2011). Echinochloa pyramidalis is recommended as a suitable plant for forage production in treatment wetlands (Pare et al., 2009). In Pakistan the seeds of Oryza sativa are used to ease delivery and release of placenta in cattle, the seed of Zea mays fluor in the form of paste is given to goats to cure blood in urine (Shah et al., 2012).

30 of the plants sampled were noted by Focho et al., 2009 as plants used to treat diseases of the reproductive system such as gonorrhoea, syphilis, candidiasis and female infertility in Ndop Central Sub-division, Cameroon. Adjanohoun et al., 1996 recorded 20 of the plants as medicinal plants of Cameroon. The leaf and root of Ficus benghalensis is used in Central Punjab, Pakistan for increasing human male sexual power. Stem is used in furniture utilities and as fuel (Zereen and Khan, 2012). Mangifera indica, Psidium guajava, Musa paradisiaca and Saccharum officinarum are used to treat different ailments in Nepal (Malla and Chhetri, 2009). Simbo, 2010 cited 19 of these plant species as medicinal plants in Babungo, North West Region Cameroon.

Some of the plants sampled are melliferous plants, these include some native melliferous plants such as Ageratum conyzoides, Albizia adianthifolia, Albizia gummifera, Albizia zygia, Alchornea laxiflora, Aspilia africana, 
Bidens pilosa, Calliandra callothyrsus, Canarium schweinfurthii, Elaeis guineensis, Emilia coccinea, Entada abyssinica, Erythrina senegalensis, Harungana madagascariensis, Leucaena leucocephala, Mangifera indica, Piliostigma thonningii, Polyscias fulva, Syzygium guineense, Terminalia glaucescens, Tithonia diversifolia, Urena lobata, Vernonia amygdalina and Voacanga africana (Ingam, 2011). Some of the plants are exotic melliferous plants such as Alchornea cordifolia, Hibiscus rosa-sinensis, Lantana camara, Musa sapientum, Persea americana, Phaseolus vulgaris, Psidium guajava and Zea mays (Ingam, 2011).

Only 25 of the plants sampled were recorded as plants of Mt. Cameroon (Cable and Cheek, 1998) and only 14 of the 151 plants sampled are found on Mount Oku and Ijim Ridge, Cameroon (Cheek et al., 2000). Only 8 of the plants sampled are plants of Dom in the Bamenda Highlands, Cameroon (Cheek et al., 2010). Harvey et al., 2010 recorded only six of these plants in the Lebialem Highlands, Cameroon.

Most of the species actually present have not been previously recorded and are becoming rare. Some grazers complain that fire is the major threat to these fodder/forage plants. It destroys some plant species, leading to species extinction, desertification, and the contribution of changing land use to global warming. Norgrove (2008) reports savannahs are rendered less useful for grazing and this negatively affects pastoralist's livelihoods. The results of land degradation, pasture depletion, poor nutritional value of forage and degradation of water catchments leave livestock with no alternative than to encroach into the farm lands precipitating conflicts between graziers and their neighbouring farmers.

The goats, sheep, cattle, pigs and chickens are very important during Christmas feast, feast of the Ramadan, marriages and dead celebrations. Sheep play an important socio-economic role in the life of the population, particularly Moslems. The goats, sheep, cattle, pigs and chickens are used for meat and fattening of these animals for sale is an important economic activity. Goats and sheep provide over $13 \%$ of all meat consumed in Cameroon (MINEPIA, 2002). Traditional feeding of goats and sheep is based on agricultural byproducts, grazing on fallow, scavenging and browsing (Pamo, 2008).

Out of the 151 plant species sampled, a few are also used as fodder elsewhere, some also have other functions in
Ndop and elsewhere, signifying that these plants are not only important as fodder but also have other functions. Some of the rangelands elsewhere may be highly degraded than in Ndop. In other areas people may commercialised fodder plants thus cultivating some particular species. In Ndop they mostly rely on natural pastures.

\section{Guidelines}

Carrying out agroforestry and agroecological agriculture. Increasing the stock through planting (fencing material, direct sowing). Plants of the Moraceae family, particularly Ficus spp. are readily browsed by ruminants, are fire resistant and are also recommended for life fencing. Their use on rangelands could be of advantage to range resource utilizers since they are readily browsed by ruminants and are fire resistant (Neba, 2010). Certain areas should be reserved for the dry season, either as standing hay for direct grazing or for the preparation of conserved forages (such as hay or silage). Direct seeding mulch-based cropping systems (DMC) of cover plants like grasses (Brachiaria sp., Eleusine sp., Panicum sp., Sorghum and leguminous plants (Cajanus cajan), thus preparing fields for subsequent crops ("biological tillage") can be adopted to improve livestock nutrition by combining crop and livestock farming through the use of cover plants as forage. This will also combat desertification, and maintain the resilience of agrarian systems. This offers solutions to the main short-term environmental challenges facing the world, especially in sub-arid to sub-humid areas threatened by desertification, through: erosion control, soil protection and costeffective fertility regeneration. Cover plants will also in this way aid in the Clean Development Mechanism and the United Nations Framework Convention on Climate Change (UNFCCC).

Applying improved agricultural practices is advantageous. Intercropping practices offer many advantages, but improved understanding of the ecological mechanisms associated with planned special diversity, including associated additional benefits, is needed to enhance the benefits achieved. There is the scope for farmers to increase cowpea and system productivity in the Guinea-savannah by intercropping maize with medium maturing improved cowpea varieties such as IT97K and A2214 (Maurice et al., 2010). Instead of using uncontrolled fire and too much application of fertilizers to have high crop yield which is detrimental to the soil, Maurice et al. (2010) recommended that pure cowpea culture or simultaneous cowpea/maize cropping can produce high yield. 
The nutritive values of the key fodder and forage plants should be determined and sensitisation by carrying out environmental education.

\section{Conclusion}

The savannahs of Ngoketunjia Division, North Western Cameroon are endowed with fodder plants (herbs, shrubs and tree species) which are an important feed source for livestock in the area. The majorities of the plants are either getting rare or are rare and very rare plants due to major threats like uncontrolled fire and overexploitation. Details of graze, browse production, nutritive value, storage systems and trade are still lacking for most of the species identified.

\section{Recommendations}

For optimum utilisation of fodder herbs, trees and shrubs, it is essential that details of production, palatability, nutritive value and deleterious substances of the species are measured. It is very vital to promote fodder production and trade and to improve on the storage systems.

Integration of livestock production within local farming systems. The use of browse plants for fencing land. Direct seeding mulch-based cropping systems (DMC) of cover plants like grasses (Brachiaria lata, Eleusine indica, Panicum repens, Sorghum bicolor and leguminous plants (Cajanus cajan).

\section{Conflict of interest statement}

Authors declare that they have no conflict of interest.

\section{Acknowledgement}

We thank the informants for their cooperation, and all the field assistants who supported us in this study. Special thanks to Ajarah Hasan, Mr. Bomboh Godlove Ngwiangeh, Mr. Nkwain Polynius Majas, Mr. Vati Cyprian, Lucha Titus, Malam Duni Adamou Duma. Thanks to Mr. Tadjouteu Fulbert, Mr Paul Mezili, Dr. Jean Michel Onana and Mr. Yombo Christian of the National Herbarium. Also Mr. Maurice Betafu (of blessed memory) and Mr. Elias Ndive of the Limbe Botanical Herbarium. The Tropical Biology Association and the WWF's Education For Nature for their Professional Development grant through the support of the Liz Claiborne Art Ortenberg Foundation to attend the 2015 Students Conference of the Tropical Biology Association Alumni Group at the University of
Ghana from June 9-12, 2015 in which this work was presented. Biosciences eastern and central AfricaInternational Livestock Research Institute (BecA-ILRI Hub) for participating in their workshop on Scientific Research Paper Writing from the $26^{\text {th }}-30^{\text {th }}$ of October 2015 at ILRI Ethiopia, Pr. Peter Willadsen for earlier review of this paper. The work was partly funded through Research modernization allowance from the Ministry of Higher Education (MINESUP) Cameroon.

\section{References}

Adjanohoun, J. E., Aboubakar, N., Dramane, K., Ebot, M. E., Ekpere, J. A., Enow-Orock, E. J., Focho, D., Gbile, Z., O., Kamanyi, A., Kamsukom, J., Keita, A., Mbenkum, Mbi, C. N., Mbiele, A. L., Mbome, L. L., Mubiru, N. K., Nancy, W. L., Nkongmeneck, B., Satabie, B., Sofowora, A., Tamze, V., Wirmum, C. K., 1996. Traditional Medicine and Pharmacopoeia. Contribution to Ethnobotanical and Floristic Studies in Cameroon. OAU /STRC Lagos Nigeria. pp.422-491.

Asah, H. A., 1994. Potentials of multipurpose trees and shrubs in traditional crop-livestock production systems of the Bamenda Highlands of Cameroon. Proceedings of Agroforestry Harmonization Workshop RCA Bambili, April 4-7, 1994.

Bahru, T., Asfaw, Z., Demissew, S., 2014. Ethnobotanical study of forage/fodder plant species in and around the semi-arid Awash National Park Ethiopia. J. For. Res. 25(2), 445-454.

Bele, M. Y., Focho, D. A., Egbe, E. A., Chuyong, B. G., 2011. Ethnobotanical survey of the uses of Annonaceae around mount Cameroon. Afr. J. Plant Sci. 5(4), 237-247.

Cable, S., Cheek, M., 1998. The plants of Mt. Cameroon. A Conservation Checklist. Royal Botanic Gardens, Kew. Mount Cameroon Project, Limbe. Whitstable, Kent. 198p.

Cheek, M., Harvey, Y., Onana, J. M., 2010. The plants of Dom, Bamenda Highlands, Cameroon. A Conservation Checklist. RBGK. IRAD-NHC. 162p.

Cheek, M., Onana, J. M., Pollard, B. J., 2000. The Plants of Mount $\mathrm{Oku}$ and the Ijim Ridge, Cameroon. A Conservation Checklist. RBGK. 211p.

Convention on Biological Diversity (CBD), 2014. Review of Global Assessments of land and Ecosystem Degradation and the Relevance in Achieving the Land-based Aichi Biodiversity Targets. Conference of the parties to the Convention on Biological Diversity. $\mathrm{UNEP} / \mathrm{CBD} / \mathrm{COP} / 12 / \mathrm{INF} / 18$

Feedipedia, 2012-2013. Animal feed Resources Information System-INRA CIRAD AFZ and FAO.

Focho, D. A., Nkeng, E. A. P., Lucha, C. F., Ndam, W. T., Afegenui, A., 2009. Ethnobotanical survey of plants used to treat diseases of the reproductive system and preliminary phytochemical screening of some species of Malvaceae in Ndop Central Sub-division, Cameroon. J. Med. Plants Res. 3(4), 301-314. 
Ghosh, S. B., 2012. Biodiversity and wild Fodder of Gorumara National park in West Bengal, India. Fodder plants and Habitat of Gorumara National Park. J. Environ. Ecol. 3(1), 18-35.

Harvey, Y., Tchiengué, B., Cheek, M., 2010. The Plants of Lebialem Highlands, Cameroon . A Conservation Checklist. RBGK. IRAD-NHC. 157p.

Holmström, 2013. Fodder to ruminants within agroforestry systems in Rwanda, species and management. Swedish University of Agricultural Sciences, Faculty of Veterinary medicine and Animal Science. Department of Animal Nutrition and management. Uppsala. 26p.

Ingam, 2011. Melliferous plants for Cameroon Highlands and Adamaoua Plateau honey. CIFOR. 28p.

International Livestock Research Institute (ILRI), 2010. Improvement of Fodder Markets and Identification of Crop Varieties with Improved Fodder Characteristics in Selected Disadvantaged Areas of India. Project Report OFID: The OPEC Fund for International Development. C G Centres Block B, National Agricultural Science Centre, Dev Prakash Shastri Marg, New Delhi 110012, India. 30p www:http://www.cgiar.org/ilri/

Jamala, G. Y., Tarimbuka, I. L., Moris, D., Mahai, S., 2013. The scope and potentials of fodder trees and shrubs in Agroforestry. J. Agric. Vet. Sci. 5(4), 11-17.

Jata, S. K., Nedunchezhian, M., Misra, R. S., 2011. The Tripple ' $\mathrm{f}$ ' (food, fodder and fuel) crop sweet potato (Ipomoea batatas (L.) Lam.). Orissa Review. pp.82-92.

Konsala, S., Bernard-Aloys, N., Gilbert, T., Roger-Corneille, F., Bernard, F., Elvire-Hortense, B., Tchobsala, 2013. Use of wild trees and shrubs as fodder and traditional veterinary medicine in Cameroon: ecological impacts and conservation. Int. J. For. Soil Erosion. 3(3), 87-91.

Malla, B., Chhetri, R. B., 2009. Indigenous knowledge on ethnobotanical plants of Kavrepalanchowk District. Katmandu Univ. J. Sci. Engg. Technol. 5(2), 96-109.

Maurice, G., Albert, N., Isidore, T., FranÇois, A., 2010. Altering the time of intercropping cowpea (Vigna unguiculata (L.) Walp.) relative to maize (Zea mays L.): A food production strategy to increase crop yield attributes in Adamawa-Cameroon. World J. Agric. Sci. 6(5), 473479.

Mbarga, B., 2010. Triosième Recensement Général de la Population et de l'Habitat ( $\left.3^{\text {rd }} \mathrm{RGPH}\right)$. Third General Population and Housing Census. Rapport de Presentation des Resultats Definitifs. Yaounde Cameroon. pp.51-53.

MINEF, 1999. Annual Report of Activities carried out by the Divisional Section for Forestry, Ngoketunjia. MINEF, Cameroon, pp.2-4.

MINEPIA, 2002. La stratégie sectorielle de l'élevage, des pêches et des industries animales. MINEPIA. Cameroun. $93 \mathrm{p}$.

Muyekho, F. N., Lusweti, F., Cheruiyot, D. T., Kamau, J. N., Gitahi, F., Kungu, J., Kute, C., 2005. Forage crops for western Kenya. Kari-Kitale. 27p.

Neba, E., 2010. Indigenous trees and shrubs in silvopastoral systems of the Bamenda highlands of Cameroon. Global J.
Human Social Sci. 10(3), 56-64.

Neba, N. E., 2009. Cropping systems and post-cultivation vegetation successions: Agro-ecosystems in Ndop, Cameroon. J. Human Ecol. 27(1), 27-33.

Nkouandou, I., 2005. Divisional delegation of forestry and wildlife for Ngoketunjia, Cameroon. Annual Report. pp.2-7.

Norgrove, L., Tueche, R., Dux, J., Yonghachea, 2008. Chromolaena odorata: the benevolent dictator? Chromolaena odorata Newslet. 17, 1-3.

Osawaru, M. E., Danin-Ogbe, F. M., 2010. Ethnobotanical studies of West African Okra [Abelmoschus caillei (A.Cher) Stevels] from some tribes of South Western Nigeria. Sci. World J. 5(1), 36-41.

Pamo, E. T., 2008. Country Pasture/Forage Resource Profiles, Cameroon. FAO. 52p.

Pamo, T.E., Tendonkeng, F., Kana, J. R., Boukila, B., Nanda, A. S., 2006b. Effects of Calliandra calothyrsus and Leucaena leucocephala supplementary feeding on goat production in Cameroon. Small Ruminant Res. 65, 31-37.

Pamo, T. E., Fonteh, F. A., Tendonkeng, F., Kana, J. R., Boukila, B., Djaga, P.J., Fomewang II, G., 2006 a. Influence of supplementary feeding with multipurpose leguminous tree leaves on kid growth and milk production in the West African dwarf goat. Small Ruminant Res. 63, $142-149$.

Pare, M-. M. N., Doulaye Koné, D., Kengne, I., Amougou, A., 2009. Nutritive value of Echinochloa pyramidalis, a forage plant used for treating faecal sludge and wastewater. Daniel Thevenot. $9^{\text {th }}$ World Wide Workshop for Young Environmental Scientists WWW-YES-Brazil2009: Urban waters: resource or risks? Belo Horizonte, MG, Brazil. WWW-YES-2009-Br (6), WWW-YES. <hal00593294>

Shah, G. M., Ahmad, M., Arshad, M., Khan, M. A., Zafar, M., Sultana, S., 2012. Ethno-phyto-veterinary medicines in Northern Pakistan. J. Anim. Plant Sci. 22(3), 791-797.

Simbo, D. J., 2010. An ethnobotanical survey of medicinal plants in Babungo, Northwest Region, Cameroon. J. Environ. Ecol. 6, 1-8.

Speedy, A., Pugliese, P. L., 2011. Legume trees and other fodder trees as protein sources for livestock. Proceedings of the FAO Expert Consultation held at the Malaysian Agricultural Research and Development Institute (MARDI) in Kuala Lumpur, Malaysia, 14-18 October 1991. FAO Animal Production and Health Paper. 102, 1217.

Tabuti, R. S., Lye, K.A., 2009. Fodder plants for cattle in Kaliro District, Uganda. Afr. Study Monogr. 30(3), 161170.

The World Bank, 2012. Intensification of livestock production systems in the North West Region of Cameroon: A Southto-South Collaboration for Technology Transfer. The Tugi Silvopastoral Project. Report Number: 66794-CM. Washington, DC 20433. 72p.

van Wilgen, B. W., Biggs, H. C., Regan, S. P. O., Mare, N., 2000. A fire history of the savanna ecosystems in the 
Kruger National Park, South Africa, between 1941 and 1996. South Afr. J. Sci. 96, 167-178.

Wirsiy, F. Y., 2011. Annual report of activities carried out by the Divisional Delegation of Agriculture and Rural Development, Ngoketunjia. Ministry of Agriculture and Rural Development, Cameroon. pp.1-2.

Wirsiy, F.Y., 2013. $1^{\text {st }}$ Semester report carried out by the Divisional Delegation of Agriculture and Rural
Development, Ngoketunjia. MARD, Cameroon. pp.1-2.

Zereen, A., Khan, Z. U. D., 2012. A survey of ethnobotanically important trees of Central Punjab, Pakistan. Biologia (Pakistan). 58(1\&2), 21-30.

Zimmermann, T., 1996. Watershed Resources Management in the Western Highlands. Helvetas, Bamenda.

\section{How to cite this article:}

Lucha, C. F., Chuyong, G. B., 2016. Ethnobotanical survey of fodder/forage plant species in range and farming systems in the savannahs of Ngoketunjia, North Western Cameroon. Int. J. Curr. Res. Biosci. Plant Biol. 3(6), 50-72. doi: http://dx.doi.org/10.20546/ijcrbp.2016.306.008

\section{$\underline{\text { List of Appendices }}$}

Appendix 1: Fodder/Forage plant families, collection number, species and common/vernacular names.

Appendix 2: Life forms, parts used and animals.

Appendix 3: The frequency of the fodder/forage plants in Ngoketunjia. 
Appendix 1: Fodder/Forage Plant families, collection number, species and common/vernacular names.

\begin{tabular}{|c|c|c|c|c|}
\hline No. & Family & $\begin{array}{l}\text { Collection } \\
\text { No. }\end{array}$ & Species & Common/Vernacular name \\
\hline 1 & Acanthaceae & 063 & Dychoriste perrotteti (Nees) O. Ktze & Botoron (Mbororo) \\
\hline \multirow{2}{*}{2} & Amaranthaceae & 136 & Amaranthus hybridus L. & Green, feih (Bamunka) \\
\hline & & 137 & Amaranthus spinosus L. & \\
\hline 3 & Amaryllidaceae & 090 & Scadoxus multiflorus (Martyn) Raf. & \\
\hline 4 & Anacardiaceae & 026 & Mangifera indica $\mathrm{L}$. & Manguteh (Bamunka), Mongoroh (Mbororo) \\
\hline 5 & Annonaceae & 025 & Annona senegalensis Pers. & Wild african custard apple, Dokonih (Mbororo) \\
\hline \multirow[t]{2}{*}{6} & Araceae & 119 & Colocasia esculenta Schott & Ibo coco, achu coco, taro \\
\hline & & 120 & Xanthosoma sagittifolium K.Koch & Macabo \\
\hline \multirow[t]{2}{*}{7} & Araliaceae & 066 & Cussonia arborea Hochst. Ex A Rich & Yamasehtoh (Mbororo) \\
\hline & & 069 & Cussonia djalonensis A.Chev & Oyahih (Mbororo) \\
\hline \multirow[t]{4}{*}{8} & Arecaceae & 152 & Cocos nucifera L. & Coconu, tneikwokeh (Bamunka) \\
\hline & & 148 & Elaeis guineensis Jacq & King tree, Teng (Bamunka) \\
\hline & & 059 & Phoenix reclinata Jacq. Var. reclinata & Date palm, Kehnah (Bamunka) \\
\hline & & & Phoenix sylvestris & Dailih (Mbororo) \\
\hline \multirow[t]{14}{*}{9} & Asteraceae & 109 & Ageratum conyzoides $\mathrm{L}$. & Goatweed, kinggrass \\
\hline & & 061 & Aspilia africana (Pers.) C.D. Adams & $\begin{array}{l}\text { Iodine grass, Tahkamahoh (Mbororo), } \\
\text { Nchinga (Bamunka) }\end{array}$ \\
\hline & & 112 & Bidens pilosa $\mathrm{L}$. & Black jack \\
\hline & & 023 & Echinops gracilis O. Hoffm & Monkey kola, Gorodoro mongehkola \\
\hline & & 024 & Echinops lanceolatus Mattf. & Monkey kola, Dorodoro (Mbororo) \\
\hline & & 087 & Emilia coccinea (Sims.) G. Don. & \\
\hline & & 079 & Helichrysum sp. & \\
\hline & & 093 & Spilanthes filicaulis (Schumach. \& Thonn.) C.D.Adams. & Eye for fowl, nyuohnyi (Bamunka) \\
\hline & & 129 & Tithonia diversifolia A. Gray. & Sunflower \\
\hline & & 027 & Vernonia guineensis Benth & Ginseng, Hihbih (Bamunka) \\
\hline & & 044 & Vernonia ambigua Kotschy \& Peyr. & Sabolo (Mbororo) \\
\hline & & 113 & Vernonia amygdalina Del. & Bitterleaf, ndole \\
\hline & & 077 & Vernonia sp. & \\
\hline & & 078 & Vernonia sp. & \\
\hline 10 & Azaliaceae & 108 & Polyscias fulva (Hiern). Harms. & \\
\hline 11 & Azollaceae & 092 & Azolla africana Desv. & Mosquito fern \\
\hline 12 & Burseraceae & 149 & Canarium schweinfurtii Engl. & Black, bevakeh (Bamunka) \\
\hline \multirow[t]{3}{*}{13} & Caesalpiniaceae & 097 & Cassia mimosoides L. & \\
\hline & & 104 & Cassia siamea Lam. & \\
\hline & & 040 & Piliostigma thonningii (Schum.) Milne-Red head & Barkerih (Mbororo) \\
\hline \multirow[t]{2}{*}{14} & Combretaceae & 072 & Combretum glutinosum Perr ex. DC & \\
\hline & & 047 & Terminalia laxifolia Engl. \& Diels & Njoboh (Bamunka) \\
\hline
\end{tabular}

C. F. Lucha and G. B. Chuyong (2016) / Ethnobotanical Survey of Fodder/Forage Plant Species in Range and Farming Systems in the Savannahs of Ngoketunjia, North Western Cameroon 


\begin{tabular}{|c|c|c|c|c|}
\hline No. & Family & $\begin{array}{l}\text { Collection } \\
\text { No. }\end{array}$ & Species & Common/Vernacular name \\
\hline & & 048 & Terminalia glaucescens Planch ex. Benth & Bohdih (Mbororo) \\
\hline 15 & Convolvulaceae & 138 & Ipomoea batatas (L.) Lam. & Sweet potatoes, keuneh (Bamunka) \\
\hline 16 & Cucurbitaceae & 151 & Cucurbita mixta Pang. & Pumpkin, cheng (Bamunka) \\
\hline \multirow[t]{3}{*}{17} & Cyperaceae & 098 & Cyperus difformis L. & \\
\hline & & 096 & Fimbristylis ferruginea (L.) Vahl. & \\
\hline & & 018 & Fimbristylis littoralis Gaudet & \\
\hline \multirow[t]{3}{*}{18} & Euphorbiaceae & 147 & Alchornea cordifolia Schum and Thonn & \\
\hline & & 049 & Croton macrostachyus Hochst. Ex. Del. & \\
\hline & & 131 & Manihot esculenta Crantz & Cassava, chachun (Bamunka) \\
\hline \multirow[t]{22}{*}{19} & Fabaceae & 141 & Arachis hypogea $\mathrm{L}$. & Nene (Bamunka) \\
\hline & & 110 & Cajanus cajan (L.) Millsp. & Pigeonpea, greenbeans \\
\hline & & 103 & Calliandra calothyrsus Meisn. & Calliandra \\
\hline & & 074 & Calopogonium mucunoides Desv. & \\
\hline & & 075 & Dalbergia lactea Vatke & Pehlohary (Mbororo) \\
\hline & & 055 & Desmodium ascendens (Sw.) DC & Bihligewah (Mbororo) \\
\hline & & 070 & Desmodium repandum (Vahl.). De & \\
\hline & & 056 & Desmodium canum (J.F. (Jmel.) Schinz \& Thell & \\
\hline & & 105 & Entada abyssinica Steud. ex A. Rich. & \\
\hline & & 041 & Entada africana Guill \& Perr. & $\begin{array}{l}\text { Tchikwohkeh (Bamunka), Fuluh (Bamessing), } \\
\text { Pelowahih (Mbororo) }\end{array}$ \\
\hline & & 052 & Erythrina sigmoidea Hua & \\
\hline & & 057 & Gliricidia sepium (Jacq.) Walp. & \\
\hline & & 115 & Glycine $\max (\mathrm{L}$.$) Merr$ & Soyabeans, soja beans \\
\hline & & 082 & Kotschya schweinfurthii (Taub.) Dewit \& Duvign & Black \\
\hline & & 106 & Leucaena leucocephala (Lam.) de Wit. & \\
\hline & & 143 & Phaseolus vulgaris L. & Beans, wuoa (Bamunka) \\
\hline & & 083 & Pseudarthria hookeri Wight et Arn & \\
\hline & & 107 & Sesbania macrantha Phil. \& Hutch & \\
\hline & & 080 & Vigna multineruis Hutch et Dalz. & Herb, climbing, $70 \mathrm{~cm}$ \\
\hline & & 081 & Vigna nigritia Hook. f & Herb, climbing, $1.5 \mathrm{~m}$ \\
\hline & & 125 & Vigna subterranea (L.) Verdc. & Bambara groundnut \\
\hline & & 114 & Vigna unguiculata (L.) Walp. & Cowpea, keukwusoh, wuokeh (Bamunka) \\
\hline 20 & Hymenocardiaceae & 071 & Hymenocardia cacida Tul. & Yamasetoh (Mbororo) \\
\hline 21 & Hypericaceae & 039 & Harungana madagascariensis Lam. ex Poir & Bonechi (Bamunka), Brukalih(Mbororo) \\
\hline 22 & Loganiaceae & 073 & Anthocleista djalonensis A. Chev & Bohgih (Mbororo) \\
\hline 23 & Lamiaceae & 006 & Hyptis lanceolata Poir & Cow grass, Dokory (Mbororo) \\
\hline 24 & Lauraceae & 134 & Persea americana Mill. & Pear, bea (Bamunka) \\
\hline 25 & Malvaceae & 126 & Hibiscus rosa-sinensis L. & Flower \\
\hline
\end{tabular}

C. F. Lucha and G. B. Chuyong (2016) / Ethnobotanical Survey of Fodder/Forage Plant Species in Range and Farming Systems in the Savannahs of Ngoketunjia, North Western Cameroon 


\begin{tabular}{|c|c|c|c|c|}
\hline No. & Family & $\begin{array}{l}\text { Collection } \\
\text { No. }\end{array}$ & Species & Common/Vernacular name \\
\hline & & 127 & Malvaviscus arboreus var. drummondii. & Flower \\
\hline & & 060 & Sida acuta Burm.f & Bascara (Mbororo) \\
\hline & & 085 & Sida rhombifolia L. & Barji (Mbororo) \\
\hline & & 004 & Urena lobata Linn & Cow grass, Bodoroh/ kehnih (Bamunka) \\
\hline 26 & Marchantiaceae & 135 & Marchantia polymorpha $\mathrm{L}$. & Liverwort \\
\hline \multirow[t]{3}{*}{27} & Mimosaceae & 050 & Albizia adianthifolia (Schumach.) W.F. Wight & \\
\hline & & 051 & Albizia gummifera (J.F. Gmel.) C.A.Sm. & \\
\hline & & 101 & Albizia zygia (DC.) JF Macbride & \\
\hline \multirow[t]{6}{*}{28} & Moraceae & 038 & Ficus abutilifolia (Miq.) Miq & Fig, Bambamiwoh (Mbororo) \\
\hline & & 145 & Ficus benghalensis L. & Fig, gwunekeh (Bamunka) \\
\hline & & 144 & Ficus exasperata Vahl & Sand leaf \\
\hline & & 089 & Ficus ingens (Miq.) Miq. & Fig \\
\hline & & 088 & Ficus ovata Vahl & Fick tree \\
\hline & & 037 & Ficus vogelii (Miq.) Miq. & Fig, Yihbih (Mbororo) \\
\hline \multirow[t]{3}{*}{29} & Musaceae & 062 & Ensete gilletii (De Wild.) E.E. Cheesm & Monkey banana \\
\hline & & 123 & Musa sapientum $\mathrm{L}$. & Banana \\
\hline & & 124 & Musa paradisiaca $\mathrm{L}$. & Plantain, yeukeh (Bamunka) \\
\hline \multirow[t]{6}{*}{30} & Myrtaceae & 140 & Eucalyptus globulus Labill. & Eucalype, frosgarde (Bamunka) \\
\hline & & 029 & Psidium guajaba Linn & Quava, Guabeh (Mbororo), Megueba (Bamunka) \\
\hline & & 030 & Syzygium guineense (Willd.) DC & Bohdeh \\
\hline & & 031 & Syzygium guineense var. guineense (Willd.) DC. & \\
\hline & & 032 & Syzygium guineense var. macrocarpum (Engl.) F. & \\
\hline & & 086 & Syzygium sp. & \\
\hline \multirow[t]{5}{*}{31} & Phyllanthaceae & 043 & Bridelia ferruginea Benth & Fentebih (Bamunka) \\
\hline & & 046 & Bridelia micrantha (Hochst.) Baill & Bush coffee \\
\hline & & 102 & Bridelia speciosa Müll.Arg. & \\
\hline & & 065 & Phyllanthus amarus Schumacher et Thonning & \\
\hline & & 007 & Phyllanthus muellerianus (O. Kze) Exell & Debrokih (Mbororo) \\
\hline \multirow[t]{10}{*}{32} & Poaceae & 014 & Andropogon tectorum Schum. \& Thonn. & \\
\hline & & 005 & Brachiaria deflexa (Schumach) C.E Hubbard ex. Robyns & Cow grass, Sohtereh (Mbororo) \\
\hline & & 002 & Brachiaria lata (Schumach) C.E Hubbard & Long cow grass, Tohlejih (Mbororo) \\
\hline & & 122 & Brachiaria ruziziensis R. Germ. \& C.M. Evrard & \\
\hline & & 132 & Cymbopogon citratus $\mathrm{L}$. & Fever grass, lemon grass \\
\hline & & 121 & Echinochloa pyramidalis (Lam.) Hitchc. And Chase & Antelope, water grass, meuh (Bamunka) \\
\hline & & 099 & Eleusine indica $\mathrm{L}$. & \\
\hline & & 010 & Eragrostis atrovirens (Desf) Trin. ex Steud. & Yeikehneh (Bamunka), Rasta (Mbororo) \\
\hline & & 017 & Eragrostis ciliaris (Linn.) R. Br. & Njabor (Mbororo) \\
\hline & & 022 & Eragrostis tremula Hochst. Ex Steud & Sohnih (Mbororo) \\
\hline
\end{tabular}

C. F. Lucha and G. B. Chuyong (2016) / Ethnobotanical Survey of Fodder/Forage Plant Species in Range and Farming Systems in the Savannahs of Ngoketunjia, North Western Cameroon 


\begin{tabular}{|c|c|c|c|c|}
\hline No. & Family & $\begin{array}{l}\text { Collection } \\
\text { No. }\end{array}$ & Species & Common/Vernacular name \\
\hline & & 003 & Eragrostis tenella (Linn.) P. Beauv. ex Roem \& Schult & \\
\hline & & 117 & Hyparrhenia cymbaria (Linn.) Stapf. & Thatching grass \\
\hline & & 116 & Hyparrhenia dissoluta (Nees ex Steud.) C.E. Hubb & Thatching grass \\
\hline & & 001 & Hyparrhenia involucrata Stapf & Cow grass, kehnih (Mbororo) \\
\hline & & 013 & Hyparrhenia rufa (Nees) Stapf. & Long white red seed cow grass, kuoh (Mbororo) \\
\hline & & 100 & Imperata cylindrica $\mathrm{L}$. & Spear grass, yoankeh (Bamunka) \\
\hline & & 021 & Oryza sativa $\mathrm{L}$ & Rice, Lehshi (Bamunka) \\
\hline & & 133 & Panicum maximum Jacq. & \\
\hline & & 009 & Panicum repens Linn & Bahama grass, Pagameh (Mbororo), Kehnih (Bamunka) \\
\hline & & 151 & Paspalum distichum $\mathrm{L}$. & Water grass, sisih (Bamunka) \\
\hline & & 016 & Pennisetum pedicellatum Trin & Goat grass \\
\hline & & 094 & Pennisetum polystachion (L.) Schult. & \\
\hline & & 054 & Pennisetum purpureum K. Schumach & Elephant grass, Gi-ih (Bamunka) \\
\hline & & 095 & Pennisetum violaceum (Lam.) Rich & \\
\hline & & 015 & Peratis indica $\mathrm{L}$. & \\
\hline & & 111 & Saccharum officinarum L. & Sugarcane, soukeh (Bamunka) \\
\hline & & 011 & Setaria longiseta P.Beauv & Short black cow grass, Selbih (Mbororo) \\
\hline & & 142 & Sinarundinaria alpina (K.Schum.) C.S. Chao \& Renvoize & Indian bamboo \\
\hline & & 012 & Sporobolus pyramidalis P. Beauv & Long red seed cow grass, kohteh (Bamunka) \\
\hline & & 130 & Sorghum bicolor (L.) Moench & Guinea corn, soohyea (Bamunka) \\
\hline & & 020 & Zea mays L. & Corn, so-oh (Bamunka) \\
\hline 33 & Portulacaceae & 118 & Portulaca oleracea Linn & Pigweed \\
\hline 34 & Polygalaceae & 028 & Polygala acicularis Oliv. & \\
\hline 35 & Proteaceae & 076 & Protea argyrophaea Hutch & Debroky (Mbororo) \\
\hline \multirow[t]{4}{*}{36} & Rubiaceae & 042 & Crosopteryx febrifuga (Afzel. ex G. Don) Benth & Shunih (Mbororo) \\
\hline & & 084 & Crosopteryx $\mathrm{sp}$ & \\
\hline & & 058 & Gardenia ternifolia Schum \& Thonn & \\
\hline & & 067 & Tricalysia okelensis Hiern & Niebon (Mbororo) \\
\hline 37 & Rutaceae & 150 & Citrus sinensis (L.) Osbeck & Orange, Lamashi (Bamunka) \\
\hline 38 & Sapotaceae & 033 & Vitellaria paradoxa Gaertn.f & Bush mango, Carihy (Mbororo) \\
\hline 39 & Solanaceae & 139 & Solanum scabrum Mill. & Huckle berry, sibeh (Bamunka) \\
\hline 40 & Smilacaceae & 008 & Smilax kraussiana Meisn & Cow grass, Niaraniarageh (Mbororo) \\
\hline 41 & Sterculiaceae & 146 & Cola nitida (Vent.) Schott \& Endl. & Beih (Bamunka) \\
\hline \multirow[t]{2}{*}{42} & Tiliaceae & 064 & Triumfetta annua L.f & Niakahmeh/niakahrey (Mbororo) \\
\hline & & 091 & Christiana africana DC & \\
\hline \multirow[t]{3}{*}{43} & Verbenaceae & 128 & Lantana camara $\mathrm{L}$. & Married flower \\
\hline & & 035 & Vitex doniana Sweet & Bih (Bamunka) \\
\hline & & 045 & Vitex madiensis Oliv. & Njoboh (Bamunka) \\
\hline
\end{tabular}

C. F. Lucha and G. B. Chuyong (2016) / Ethnobotanical Survey of Fodder/Forage Plant Species in Range and Farming Systems in the Savannahs of Ngoketunjia, North Western Cameroon 


\begin{tabular}{|c|c|c|c|c|}
\hline No. & Family & $\begin{array}{l}\text { Collection } \\
\text { No. }\end{array}$ & Species & Common/Vernacular name \\
\hline & & 068 & Vitex sp. & Buhmehih (Mbororo) \\
\hline & & 053 & Voacanga africana Stapf ex Scott-Elliot & Teuneh(Bamunka), Bohmejeh (Mbororo) \\
\hline 44 & Zingiberaceae & 036 & Aframomum danielli K. Schum & Kenchou, Chukeh (Bamunka), bush pepper \\
\hline
\end{tabular}

Appendix 2: Life forms, parts used and animals.

\begin{tabular}{|c|c|c|c|c|}
\hline S. No & Species & Life forms & Part(s) used & Animal (s) \\
\hline 1 & Dychoriste perrotteti (Nees) O. Ktze & Herb & Leaves/stalk & Goat, sheep \\
\hline 2 & Amaranthus hybridus L. & Herb & Leaves/stalk & Cattle, goats, horse, sheep, pig \\
\hline 3 & Amaranthus spinosus L. & Herb & Leaves & Cattle, goats,sheep, horse \\
\hline 4 & Scadoxus multiflorus (Martyn) Raf. & Herb & Leaves & Goat, sheep \\
\hline 5 & Mangifera indica $\mathrm{L}$. & Tree & Leaves, fruits & Cattle, goats,sheep,bats, birds, snakes \\
\hline 6 & Annona senegalensis Pers & Shrub & Leaves, fruits & $\begin{array}{l}\text { Cattle, goats, sheep, horse, rodents } \\
\text { Monkey, chimpanzees, Gorilla, squirel, bird, bat }\end{array}$ \\
\hline 7 & Colocasia esculentaSchott & Tuber & Tuber & Pigs, chickens, cattle, goats, sheep \\
\hline 8 & Xanthosoma sagittifolium K.Koch & Tuber & Tuber & Pigs, chickens, cattle, goats, sheep \\
\hline 9 & Cussonia arborea Hochst. Ex A Rich & Shrub & Leaves & Cattle, horse, sheep, goat \\
\hline 10 & Cussonia djalonensis A.Chev & Shrub & Leaves & Cattle, horse, sheep, goat \\
\hline 11 & Cocos nucifera $\mathrm{L}$. & Tree & Leaves & Cattle, goats,sheep, horse \\
\hline 12 & Elaeis guineensis Jacq & Tree & Leaves & Cattle, goats,sheep, horse, grass cutter, squirel \\
\hline 13 & Phoenix reclinata Jacq. Var. reclinata & Tree & Leaves, date & Monkeys, cattle, goats, sheep, horse \\
\hline 14 & Ageratum conyzoides $\mathrm{L}$. & Herb & Leaves/stalk & Goats \\
\hline 15 & Aspilia africana (Pers.) C.D. Adams & Herb & Leaves/stalk & Goats, sheep, rabbit, cattle, guinea pig, horses \\
\hline 16 & Bidens pilosa $\mathrm{L}$. & Herb & Leaves/stalk & Cattle, goats,sheep,pigs \\
\hline 17 & Echinops gracilis $\mathrm{O}$. Hoffm & Herb & Leaves, fruit & Monkeys, goats \\
\hline 18 & Echinops lanceolatus Mattf. & Herb & Leaves, fruit & Monkeys, goats \\
\hline 19 & Emilia coccinea (Sims.) G. Don & Herb & Leaves/stalk & Goats, sheep \\
\hline 20 & Helichrysum sp & Herb & Leaves & Goats, sheep \\
\hline 21 & Spilanthes filicaulis (Schumach. \& Thonn.) C.D.Adams. & Herb & Leaves/stalk & Goats, sheep, chicken, cattle \\
\hline 22 & Tithonia diversifolia A. Gray. & Shrub & Leaves & Cattle, goats, sheep \\
\hline 23 & Vernonia guineensis Benth & Herb & Entire plant & Cattle, goats, sheep, rodents \\
\hline 24 & Vernonia ambigua Kotschy \& Peyr & Herb & Leaves/stalk & Goats, sheep \\
\hline 25 & Vernonia amygdalina Del & Shrub & Leaves & Cattle, goats,sheep,pigs \\
\hline 26 & Vernonia $\mathrm{sp}$ & Herb & Leaves & Goats, sheep \\
\hline 27 & Vernonia sp. & Herb & Leaves & Goats, sheep \\
\hline 28 & Polyscias fulva (Hiern). Harms & Shrub & Leaves & Cattle, horse, goats, sheep \\
\hline 29 & Azolla africana Desv. & Fern & Entire plant & Chicken, pig, sheep, goat, cattle, horse \\
\hline 30 & Canarium schweinfurtii Engl. & Tree & Leaves, fruits & Cattle, sheep, goats, rodents \\
\hline 31 & Cassia mimosoides L. & Shrub & Leaves & Cattle, horse, goats, sheep \\
\hline 32 & Cassia siamea Lam. & Shrub & Leaves, fruits & Cattle, horse, goats, sheep \\
\hline
\end{tabular}

C. F. Lucha and G. B. Chuyong (2016) / Ethnobotanical Survey of Fodder/Forage Plant Species in Range and Farming Systems in the Savannahs of Ngoketunjia, North 


\begin{tabular}{|c|c|c|c|c|}
\hline S. No & Species & Life forms & Part(s) used & Animal (s) \\
\hline 33 & Piliostigma thonningii (Schum.) Milne-Red head & Shrub & Leaves, fruits & Cattle, horse, goats, sheep \\
\hline 34 & Combretum glutinosum Perr ex. DC & Tree & Leaves & Cattle, horse, goats, sheep \\
\hline 35 & Terminalia laxifolia Engl. \& Diels & Tree & Leaves & Cattle, horse, goats, sheep \\
\hline 36 & Terminalia glaucescens Planch ex. Benth & Tree & Leaves & Cattle, horse, goats, sheep \\
\hline 37 & Ipomoea batatas (L.) Lam. & Tuber & Tuber, leaves & Cattle, horse, goats,sheep,pigs, rabbit, squirrel, grass cutter \\
\hline 38 & Cucurbita mixtaPang. & Climber & Leaves, fruits & Pig, goats \\
\hline 39 & Cyperus difformis L. & Sedge & Leaves/stalk & Cattle, horse, goats, sheep \\
\hline 40 & Fimbristylis ferruginea (L.) Vahl. & Sedge & Leaves/stalk & Cattle, horse, goats, sheep \\
\hline 41 & Fimbristylis littoralis Gaudet & Sedge & Leaves/stalk & Cattle, horse, goats, sheep \\
\hline 42 & Alchornea cordifolia Schum and Thonn & Herb & Leaves & Cattle, sheep, goats \\
\hline 43 & Croton macrostachyus Hochst. Ex. Del. & Tree & Leaves & Cattle, sheep, goats \\
\hline 44 & Manihot esculenta Crantz & Tuber & Leaves, tuber & Goat, sheep, cow, horse, monkey, rodents \\
\hline 45 & Arachis hypogea L. & Herb & Leaves/stalk & Cattle, sheep, goats, horse, rodents \\
\hline 46 & Cajanus cajan (L.) Millsp. & Herb & Leaves/stalk & Cattle, sheep, goats \\
\hline 47 & Calliandra calothyrsus Meisn & Shrub & Leaves, twigs & Cattle, sheep, goats \\
\hline 48 & Calopogonium mucunoides Desv. & Shrub & Leaves & Cattle, sheep, goats \\
\hline 49 & Dalbergia lactea Vatke & Shrub & Leaves & Cattle, sheep, goats \\
\hline 50 & Desmodium ascendens (Sw.) DC & Herb & Leaves/stalk & Cattle, sheep, goats \\
\hline 51 & Desmodium repandum (Vahl.). De & Herb & Leaves/stalk & Cattle, sheep, goats \\
\hline 52 & Desmodium canum (J.F. (Jmel.) Schinz \& Thell & Herb & Leaves/stalk & Cattle, sheep, goats \\
\hline 53 & Entada abyssinica Steud. ex A. Rich. & Shrub & Leaves & Cattle, horse, goats, sheep \\
\hline 54 & Entada africana Guill \& Perr. & Shrub & Leaves, fruits & Cattle, sheep, goats, monkeys \\
\hline 55 & Erythrina sigmoidea Hua & Shrub & Leaves & Cattle, sheep, goats, monkeys \\
\hline 56 & Gliricidia sepium (Jacq.) Walp. & Shrub & Leaves & Cattle, sheep, goats \\
\hline 57 & Glycine $\max (\mathrm{L}$.$) Merr.$ & Herb & Leaves/stalk & Cattle, sheep, goats,pigs, chickens \\
\hline 58 & Kotschya schweinfurthii (Taub.) Dewit \& Duvign & Tree & Leaves, fruits & Cattle, sheep, goats, rodents \\
\hline 59 & Leucaena leucocephala (Lam.) de Wit. & Shrub & Leaves & Cattle, sheep, goats \\
\hline 60 & Phaseolus vulgaris L. & Herb & Leaves/stalk & Cattle, sheep, goats,pigs, chickens \\
\hline 61 & Pseudarthria hookeri Wight et Arn & Shrub & Leaves & Cattle, sheep, goats \\
\hline 62 & Sesbania macrantha Phil. \& Hutch & Shrub & Leaves & Cattle, sheep, goats \\
\hline 63 & Vigna multineruis Hutch et Dalz & Climber & Leaves/stalk & Cattle, sheep, goats, horses \\
\hline 64 & Vigna nigritia Hook. f & Climber & Leaves/stalk & Cattle, sheep, goats, horses \\
\hline 65 & Vigna subterranea (L.) Verdc. & Herb & Leaves/stalk & Cattle \\
\hline 66 & Vigna unguiculata (L.) Walp. & Herb & Leaves/stalk & Cattle, goat, horse, sheep \\
\hline 67 & Hymenocardia cacida Tul. & Shrub & Leaves & Cattle, goat, horse, sheep \\
\hline 68 & Harungana madagascariensis Lam. ex Poir & Shrub & Leaves/bark & Cattle, goat, horse, sheep \\
\hline 69 & Anthocleista djalonensis A. Chev & Shrub & Leaves & Cattle, goat, horse, sheep \\
\hline 70 & Hyptis lanceolata Poir & Herb & Leaves/stalk & Cattle, goat, horse, sheep \\
\hline 71 & Persea americana Mill. & Tree & Leaves, twigs, fruits & Cattle, sheep, goat, pig, horse \\
\hline 72 & Hibiscus rosa-sinensis L. & Shrub & Leaves & Goats \\
\hline
\end{tabular}

C. F. Lucha and G. B. Chuyong (2016) / Ethnobotanical Survey of Fodder/Forage Plant Species in Range and Farming Systems in the Savannahs of Ngoketunjia, North Western Cameroon 


\begin{tabular}{|c|c|c|c|c|}
\hline S. No & Species & Life forms & Part(s) used & Animal (s) \\
\hline 73 & Malvaviscus arboreus var. drummondii & Shrub & Leaves & Goats \\
\hline 74 & Sida acuta Burm.f & Herb & Leaves/stalk & Cattle, goat, horse, sheep \\
\hline 75 & Sida rhombifolia L. & Herb & Leaves/stalk & Cattle, goat, horse, sheep \\
\hline 76 & Urena lobata Linn & Herb & Leaves/stalk & Cattle, goat, horse, sheep \\
\hline 77 & Marchantia polymorpha $\mathrm{L}$. & Liverwort & Entire & Cattle \\
\hline 78 & Albizia adianthifolia (Schumach.) W.F. Wight & Tree & Leaves & Cattle, goat, horse, sheep \\
\hline 79 & Albizia gummifera (J.F. Gmel.) C.A.Sm. & Tree & Leaves & Cattle, goat, horse, sheep \\
\hline 80 & Albizia zygia (DC.) JF Macbride & Tree & Leaves & Cattle, goat, horse, sheep \\
\hline 81 & Ficus abutilifolia (Miq.) Miq. & Shrub & Leaves & Cattle, goat, sheep \\
\hline 82 & Ficus benghalensis L. & Tree & Leaves & Cattle, goat, sheep \\
\hline 83 & Ficus exasperata Vahl & Shrub & Leaves & Cattle, goat, sheep \\
\hline 84 & Ficus ingens (Miq.) Miq. & Shrub & Leaves & Cattle, goat, sheep, rodents \\
\hline 85 & Ficus ovata Vahl & Tree & Leaves & Cattle, goat, sheep, rodents \\
\hline 86 & Ficus vogelii (Miq.) Miq. & Tree & Leaves & Cattle, goat, sheep \\
\hline 87 & Ensete gilletii (De Wild.) E.E. Cheesm & Shrub & Fruits, leaves & Cattle, goat, sheep, monkeys, rodents \\
\hline 88 & Musa sapientum L. & Tree & Fruits, leaves & Cattle, goat, sheep, monkeys, rodents \\
\hline 89 & Musa paradisiaca $\mathrm{L}$. & Tree & Leaves, fruits & Cattle, goat, sheep, horse, bat, bird \\
\hline 90 & Eucalyptus globulus Labill. & Tree & Leaves & Goat,sheep \\
\hline 91 & Psidium guajaba Linn & Shrub & Fruits, leaves & Cattle, goat, sheep, horse, bat, bird \\
\hline 92 & Syzygium guineense (Willd.) DC & Tree & Leaves, fruits & Cattle, goat, sheep, horse, bat, bird \\
\hline 93 & Syzygium guineense var. guineense (Willd.) DC. & Tree & Leaves, fruits & Cattle, goat, sheep, horse, bat, bird \\
\hline 94 & Syzygium guineense var. macrocarpum (Engl.) F. & Tree & Leaves, fruits & Cattle, goat, sheep, horse, bat, bird \\
\hline 95 & Syzygium sp. & Tree & Leaves, fruits & Cattle, goat, sheep, horse, bat, bird \\
\hline 96 & Bridelia ferruginea Benth. & Tree & Leaves, twigs & Cattle, goat, sheep \\
\hline 97 & Bridelia micrantha (Hochst.) Baill & Shrub & Leaves and twigs & Cattle, goat, sheep \\
\hline 98 & Bridelia speciosa Müll.Arg. & Shrub & Leaves and twigs & Cattle, goat, sheep \\
\hline 99 & Phyllanthus amarus Schumacher et Thonning & Herb & Leaves/stalk & Sheep, goats \\
\hline 100 & Phyllanthus muellerianus (O. Kze) Exell & Herb & Leaves/stalk & Sheep, goats \\
\hline 101 & Andropogon tectorum Schum. \& Thonn. & Herb & Leaves/stalk & Cattle, goat, sheep, horse \\
\hline 102 & Brachiaria deflexa (Schumach) C.E Hubbard ex. Robyns & Herb & Leaves/stalk & Cattle \\
\hline 103 & Brachiaria lata (Schumach) C.E Hubbard & Herb & Leaves/stalk & Cattle, goat, sheep, horse \\
\hline 104 & Brachiaria ruziziensis R. Germ. \& C.M. Evrard & Herb & Leaves/stalk & Cattle, goat, sheep, horse \\
\hline 105 & Cymbopogon citratus L. & Herb & Leaves/stalk & Goats \\
\hline 106 & Echinochloa pyramidalis (Lam.) Hitchc. And Chase & Herb & Leaves/stalk & Cattle, sheep, goats, fish, grasscutter \\
\hline 107 & Eleusine indica $\mathrm{L}$. & Herb & Leaves/stalk & Cattle \\
\hline 108 & Eragrostis atrovirens (Desf) Trin. ex Steud. & Herb & Leaves/stalk & Cattle \\
\hline 109 & Eragrostis ciliaris (Linn.) R. Br. & Herb & Leaves/stalk & Cattle \\
\hline 110 & Eragrostis tremula Hochst. Ex Steud & Herb & Leaves/stalk & Sheep, goats \\
\hline 111 & Eragrostis tenella (Linn.) P. Beauv. ex Roem \& Schult & Herb & Leaves/stalk & Cattle, goat, sheep, horse \\
\hline 112 & Hyparrhenia cymbaria (Linn.) Stapf. & Herb & Leaves/stalk & Cattle, goat, sheep, horse \\
\hline
\end{tabular}

C. F. Lucha and G. B. Chuyong (2016) / Ethnobotanical Survey of Fodder/Forage Plant Species in Range and Farming Systems in the Savannahs of Ngoketunjia, North Western Cameroon 


\begin{tabular}{|c|c|c|c|c|}
\hline S. No & Species & Life forms & Part(s) used & Animal (s) \\
\hline 113 & Hyparrhenia dissoluta (Nees ex Steud.) C.E. Hubb & Herb & Leaves/stalk & Cattle, goat, sheep, horse \\
\hline 114 & Hyparrhenia involucrata Stapf. & Herb & Leaves/stalk & Cattle \\
\hline 115 & Hyparrhenia rufa (Nees) Stapf. & Herb & Leaves/stalk & Cattle, goat, sheep, antelope \\
\hline 116 & Imperata cylindrica $\mathrm{L}$. & Herb & Leaves/stalk & Cattle, sheep, goat,donkey,grasscutter,squirrel, giant rat \\
\hline 117 & Oryza sativa $\mathrm{L}$ & Herb & Leaves/stalk & Cattle,sheep, goats, pig, grasscutter, horse, giant rat, rats \\
\hline 118 & Panicum maximum Jacq. & Herb & Leaves/stalk & Cattle, goat, sheep, horse \\
\hline 119 & Panicum repens Linn & Herb & Leaves/stalk & Cattle \\
\hline 120 & Paspalum distichum $\mathrm{L}$. & Herb & Leaves/stalk & Cattle, goat, sheep, antelope \\
\hline 121 & Pennisetum pedicellatum Trin. & Herb & Leaves/stalk & Cattle, goat, sheep, horse \\
\hline 122 & Pennisetum polystachion (L.) Schult. & Herb & Leaves/stalk & Cattle, sheep, goats \\
\hline 123 & Pennisetum purpureum K. Schumach & Herb & Leaves/stalk & Cattle,sheep, goats, pig, grasscutter \\
\hline 124 & Pennisetum violaceum (Lam.) Rich. & Herb & Leaves/stalk & Cattle, goat, sheep, horse \\
\hline 125 & Peratis indica $\mathrm{L}$. & Herb & Leaves/stalk & Cattle, sheep, goats \\
\hline 126 & Saccharum officinarum L. & Herb & Leaves/stalk & Cattle, goats, sheep, pigs, grass cutter \\
\hline 127 & Setaria longiseta P.Beauv. & Herb & Leaves/stalk & Cattle, goat, sheep, horse \\
\hline 128 & Sinarundinaria alpina (K.Schum.)C.S. Chao \& Renvoize & Shrub & Leaves & Cattle, sheep, goats \\
\hline 129 & Sporobolus pyramidalis $\mathrm{P}$. Beauv. & Herb & Leaves/stalk & Pigs, goats, sheep, chicken \\
\hline 130 & Sorghum bicolor (L.) Moench & Herb & Leaves/stalk & Cattle, goats, sheep, rabbit, grass cutter,squirel, giant rat \\
\hline 131 & Zea mays L. & Herb & Leaves/stalk & Cattle, sheep, goats, grass cutter, giant rat \\
\hline 132 & Portulaca oleracea Linn. & Herb & Leaves/stalk & Cattle \\
\hline 133 & Polygala acicularis Oliv. & Herb & Leaves/stalk & Cattle, goat, sheep, horse \\
\hline 134 & Protea argyrophaea Hutch. & Shrub & Leaves & Cattle \\
\hline 135 & Crosopteryx febrifuga (Afzel. ex G. Don) Benth & Shrub & Leaves, fruits & Cattle, sheep, goats, rodents \\
\hline 136 & Crosopteryx sp. & Shrub & Leaves and twigs & Cattle, sheep, goats, rodents \\
\hline 137 & Gardenia ternifolia Schum \& Thonn. & Shrub & Leaves, twigs & Cattle, sheep, goats, rodents \\
\hline 138 & Tricalysia okelensis Hiern. & Shrub & Leaves & Cattle, sheep, goats, rodents \\
\hline 139 & Citrus sinensis (L.) Osbeck & Tree & Leaves & Goats \\
\hline 140 & Vitellaria paradoxa Gaertn.f & Tree & Leaves, twigs, fruits & Cattle, sheep, goats, rodents \\
\hline 141 & Solanum scabrum Mill. & Herb & Leaves/stalk & Cattle, horse \\
\hline 142 & Smilax kraussiana Meisn & Herb & Leaves/stalk & Cattle, sheep, goats \\
\hline 143 & Cola nitida (Vent.) Schott \& Endl. & Tree & Leaves and twigs & Cattle, sheep, goats, rodents, bat \\
\hline 144 & Triumfetta annua L.f. & Herb & Leaves & Cattle, sheep, goats, rodents \\
\hline 145 & Christiana africana $\mathrm{DC}$ & Herb & Leaves/stalk & Goats \\
\hline 146 & Lantana camara $\mathrm{L}$. & Shrub & Leaves & Goats, sheep, rodents \\
\hline 147 & Vitex doniana Sweet & Tree & Leaves, twigs & Goats, cattle \\
\hline 148 & Vitex madiensis Oliv. & Tree & Leaves, twigs & Cattle, goats \\
\hline 149 & Vitex sp. & Shrub & Leaves & Cattle, goats \\
\hline 150 & Voacanga africana Stapf ex Scott-Elliot & Shrub & Fruits, leaves & Cattle,goat,sheep,bat \\
\hline 151 & Aframomum danielli K. Schum & Herb & Fruits, leaves & Goat,sheep \\
\hline
\end{tabular}


Appendix 3: The frequency of the fodder/forage plants in Ngoketunjia.

\begin{tabular}{|c|c|}
\hline Species & Frequency \\
\hline Pennisetum purpureum K. Schumach & 450 \\
\hline Brachiaria lata (Schumach) C.E Hubbard & 410 \\
\hline Oryza sativa $\mathrm{L}$. & 408 \\
\hline Brachiaria deflexa (Schumach) C.E Hubbard ex. Robyns & 255 \\
\hline Hyparrhenia rufa (Nees) Stapf. & 230 \\
\hline Terminalia glaucescens Planch ex. Benth & 215 \\
\hline Terminalia laxifolia Engl. \& Diels & 212 \\
\hline Hyparrhenia involucrata Stapf & 210 \\
\hline Combretum glutinosum Perr ex. DC & 205 \\
\hline Hyparrhenia cymbaria (Linn.) Stapf. & 205 \\
\hline Piliostigma thonningii (Schum.) Milne-Red head & 200 \\
\hline Entada africana Guill \& Perr & 112 \\
\hline Panicum maximum Jacq. & 104 \\
\hline Annona senegalensis Pers & 100 \\
\hline Entada abyssinica Steud. ex A. Rich. & 100 \\
\hline Vernonia amygdalina Del & 85 \\
\hline Eragrostis atrovirens (Desf) Trin. ex Steud. & 85 \\
\hline Eleusine indica $\mathrm{L}$. & 80 \\
\hline Eragrostis tenella (Linn.) P. Beauv. ex Roem \& Schult & 78 \\
\hline Eragrostis tremula Hochst. Ex Steud & 77 \\
\hline Elaeis guineensis Jacq & 72 \\
\hline Eragrostis ciliaris (Linn.) R. Br. & 70 \\
\hline Phoenix reclinata Jacq. Var. reclinata & 65 \\
\hline Amaranthus hybridus L. & 50 \\
\hline Leucaena leucocephala (Lam.) de Wit. & 44 \\
\hline Echinops gracilis O. Hoffm & 42 \\
\hline Mangifera indica $\mathrm{L}$. & 40 \\
\hline Cocos nucifera $\mathrm{L}$ & 40 \\
\hline Vigna multineruis Hutch et Dalz & 40 \\
\hline Urena lobata Linn. & 40 \\
\hline Brachiaria ruziziensis R. Germ. \& C.M. Evrard & 40 \\
\hline Echinops lanceolatus Mattf. & 39 \\
\hline Ipomoea batatas (L.) Lam. & 35 \\
\hline Manihot esculenta Crantz & 35 \\
\hline Vigna nigritia Hook. $\mathrm{f}$ & 35 \\
\hline Tithonia diversifolia A. Gray. & 34 \\
\hline Vigna unguiculata (L.) Walp. & 32 \\
\hline Calliandra calothyrsus Meisn & 30 \\
\hline Vigna subterranea (L.) Verdc. & 30 \\
\hline Persea americana Mill. & 30 \\
\hline Ficus benghalensis L. & 30 \\
\hline Solanum scabrum Mill. & 30 \\
\hline Spilanthes filicaulis (Schumach. \& Thonn.) C.D.Adams. & 28 \\
\hline
\end{tabular}

C. F. Lucha and G. B. Chuyong (2016) / Ethnobotanical Survey of Fodder/Forage Plant Species in Range and Farming Systems in the Savannahs of Ngoketunjia, North Western Cameroon 


\begin{tabular}{|c|c|}
\hline Species & Frequency \\
\hline Ficus exasperata Vahl. & 26 \\
\hline Fimbristylis littoralis Gaudet & 25 \\
\hline Arachis hypogea L. & 25 \\
\hline Ficus ovata Vahl. & 25 \\
\hline Vitex doniana Sweet & 25 \\
\hline Ficus vogelii (Miq.) Miq. & 22 \\
\hline Saccharum officinarum L. & 22 \\
\hline Vitex madiensis Oliv. & 22 \\
\hline Fimbristylis ferruginea (L.) Vahl. & 20 \\
\hline Cajanus cajan (L.) Millsp. & 20 \\
\hline Erythrina sigmoidea Hua & 20 \\
\hline Pennisetum violaceum (Lam.) Rich. & 20 \\
\hline Helichrysum sp. & 18 \\
\hline Emilia coccinea (Sims.) G. Don. & 17 \\
\hline Vitex sp. & 17 \\
\hline Albizia gummifera (J.F. Gmel.) C.A.Sm. & 16 \\
\hline Psidium guajaba Linn. & 16 \\
\hline Aspilia africana (Pers.) C.D. Adams & 15 \\
\hline Vernonia guineensis Benth. & 15 \\
\hline Desmodium ascendens (Sw.) DC & 15 \\
\hline Harungana madagascariensis Lam. ex Poir & 15 \\
\hline Ficus ingens (Miq.) Miq. & 15 \\
\hline Pennisetum pedicellatum Trin. & 15 \\
\hline Dychoriste perrotteti (Nees) O. Ktze. & 14 \\
\hline Cyperus difformis $\mathrm{L}$. & 14 \\
\hline Calopogonium тисипоides Desv. & 14 \\
\hline Kotschya schweinfurthii (Taub.) Dewit \& Duvign & 14 \\
\hline Albizia adianthifolia (Schumach.) W.F. Wight & 14 \\
\hline Polygala acicularis Oliv. & 14 \\
\hline Vernonia ambigua Kotschy \& Peyr. & 13 \\
\hline Albizia zygia (DC.) JF Macbride & 13 \\
\hline Desmodium repandum (Vahl.). De & 12 \\
\hline Sesbania macrantha Phil. \& Hutch & 12 \\
\hline Hibiscus rosa-sinensis $\mathrm{L}$. & 12 \\
\hline Pennisetum polystachion (L.) Schult. & 12 \\
\hline Scadoxus multiflorus (Martyn) Raf. & 11 \\
\hline Ageratum conyzoides $\mathrm{L}$. & 10 \\
\hline Desmodium canum (J.F. (Jmel.) Schinz \& Thell & 10 \\
\hline Malvaviscus arboreus var. drummondii. & 10 \\
\hline Ficus abutilifolia (Miq.) Miq & 10 \\
\hline Syzygium guineense (Willd.) DC & 10 \\
\hline Voacanga africana Stapf. ex Scott-Elliot & 10 \\
\hline Alchornea cordifolia Schum and Thonn. & 9 \\
\hline Dalbergia lactea Vatke & 9 \\
\hline Syzygium sp. & 9 \\
\hline Sinarundinaria alpina (K.Schum.) C.S. Chao \& Renvoize & 9 \\
\hline Crosopteryx febrifuga (Afzel. ex G. Don) Benth. & 9 \\
\hline Citrus sinensis (L.) Osbeck & 9 \\
\hline Bidens pilosa $\mathrm{L}$. & 8 \\
\hline Vernonia sp. & 8 \\
\hline Cucurbita mixta Pang. & 8 \\
\hline Croton macrostachyus Hochst. Ex. Del. & 8 \\
\hline Gliricidia sepium (Jacq.) Walp. & 8 \\
\hline Syzygium guineense var. guineense (Willd.) DC. & 8 \\
\hline Bridelia ferruginea Benth. & 8 \\
\hline Paspalum distichum $\mathrm{L}$. & 8 \\
\hline
\end{tabular}

C. F. Lucha and G. B. Chuyong (2016) / Ethnobotanical Survey of Fodder/Forage Plant Species in Range and Farming Systems in the Savannahs of Ngoketunjia, North Western Cameroon 


\begin{tabular}{|c|c|}
\hline Species & Frequency \\
\hline Crosopteryx sp. & 8 \\
\hline Vernonia sp. & 7 \\
\hline Azolla africana Desv. & 7 \\
\hline Glycine $\max (\mathrm{L}$.$) Merr.$ & 7 \\
\hline Pseudarthria hookeri Wight et Arn. & 7 \\
\hline Anthocleista djalonensis A. Chev. & 7 \\
\hline Syzygium guineense var. macrocarpum (Engl.) F. & 7 \\
\hline Imperata cylindrica $\mathrm{L}$. & 7 \\
\hline Setaria longiseta P.Beauv & 7 \\
\hline Protea argyrophaea Hutch. & 7 \\
\hline Colocasia esculenta Schott & 6 \\
\hline Polyscias fulva (Hiern). Harms. & 6 \\
\hline Cassia mimosoides L. & 6 \\
\hline Musa sapientum $\mathrm{L}$. & 6 \\
\hline Bridelia micrantha (Hochst.) Baill & 6 \\
\hline Bridelia speciosa Müll.Arg. & 6 \\
\hline Andropogon tectorum Schum. \& Thonn. & 6 \\
\hline Tricalysia okelensis Hiern. & 6 \\
\hline Triumfetta annua L.f. & 6 \\
\hline Xanthosoma sagittifolium K.Koch & 5 \\
\hline Cassia siamea Lam. & 5 \\
\hline Hyptis lanceolata Poir. & 5 \\
\hline Musa paradisiaca $\mathrm{L}$ & 5 \\
\hline Echinochloa pyramidalis (Lam.) Hitchc. And Chase & 5 \\
\hline Peratis indica $\mathrm{L}$. & 5 \\
\hline Cola nitida (Vent.) Schott \& Endl. & 5 \\
\hline Christiana africana DC & 5 \\
\hline Hymenocardia cacida Tul. & 4 \\
\hline Ensete gilletii (De Wild.) E.E. Cheesm & 4 \\
\hline Phyllanthus amarus Schumacher et Thonning & 4 \\
\hline Phyllanthus muellerianus (O. Kze) Exell & 4 \\
\hline Sorghum bicolor (L.) Moench. & 4 \\
\hline Smilax kraussiana Meisn. & 4 \\
\hline Aframomum danielli K. Schum. & 4 \\
\hline Marchantia polymorpha L. & 3 \\
\hline Eucalyptus globulus Labill. & 3 \\
\hline Cymbopogon citratus L. & 3 \\
\hline Portulaca oleracea Linn. & 3 \\
\hline Gardenia ternifolia Schum \& Thonn. & 3 \\
\hline Lantana camara $\mathrm{L}$ & 3 \\
\hline
\end{tabular}

